September 2021

\title{
Restoring Causality in Attenuation: Establishing the Breadth of a Fourth Amendment Violation
}

Bryan H. Ward

Ohio Northern University Pettit College of Law

Follow this and additional works at: https://researchrepository.wvu.edu/wvlr

Part of the Constitutional Law Commons, Evidence Commons, and the Fourth Amendment Commons

\section{Recommended Citation}

Bryan $\mathrm{H}$. Ward, Restoring Causality in Attenuation: Establishing the Breadth of a Fourth Amendment Violation, 124 W. Va. L. Rev. 147 (2021).

Available at: https://researchrepository.wvu.edu/wvlr/vol124/iss1/7

This Article is brought to you for free and open access by the WVU College of Law at The Research Repository @ WVU. It has been accepted for inclusion in West Virginia Law Review by an authorized editor of The Research Repository@WVU. For more information, please contact beau.smith@mail.wvu.edu. 


\title{
RESTORING CAUSALITY TO ATTENUATION: ESTABLISHING THE BREADTH OF A FOURTH AMENDMENT VIOLATION
}

\author{
Bryan H. Ward*
}

\begin{abstract}
When the police violate a suspect's Fourth Amendment rights, what often follows is the discovery of incriminating evidence. Sometimes the evidence is discovered directly after the Fourth Amendment violation. In other situations, the evidence comes by a more indirect route and may occur long after the original Fourth Amendment violation. Courts struggle when trying to decide if the discovery of this indirectly obtained evidence was caused by the police misconduct. This causal question is important because causality acts as a limiting principle when deciding when to apply the exclusionary rule. A basic view of the exclusionary rule suggests that evidence should not be excluded when its discovery was not caused by the misconduct of the police. Yet, courts struggle with deciding the scope of a Fourth Amendment violation. The United States Supreme Court crafted the attenuation doctrine to assist in establishing the breadth of a Fourth Amendment violation. Attenuation simply stands for the proposition that not all evidence that is discovered subsequent to a Fourth Amendment violation is a consequence of that violation. Sometimes, the evidence results from an altogether different cause. If that is the case, the evidence is "attenuated" and the exclusionary rule should no longer be an issue. Yet, over time, the Supreme Court has whittled away the straightforward causal nature of attenuation and has substituted other policy-based tests to assess indirectly discovered evidence. This undermines the causal nature of attenuation and serves to diminish its utility by finders of fact. This Article suggests that the time is right to restore causality to attenuation. By modifying the situations in which attenuation is used to evaluate the causal links between illegal police conduct and the discovery of incriminating evidence and by modifying the tests used to assess attenuation, we can once again make attenuation a useful causal concept. Policy will no doubt still drive decisions on what to do with evidence discovered in such circumstances. Attenuation, however, can best be used as a measure of causality as opposed to policy-based tests that seem to do little but confound and confuse.
\end{abstract}

* Professor of Law, Ohio Northern University Pettit College of Law. I would like to thank Professor Dallan Flake for his kind assistance. 
I. INTRODUCTION

II. A SHORT HISTORY OF ATTENUATION ........................................... 151

A. Nardone v. United States: Attenuation Is Born .................... 151

B. Costello v. United States: Still an Amorphous Concept ........ 153

C. Wong Sun v. United States: Attenuation Comes to Life ........ 153

$D$. Harrison v. United States: The Beginning of the Confusion. 155

E. United States v. Giordano: A Brief Reference to Attenuation 156

F. Agius v. United States: Other Factors to Consider ............... 158

G. Brown v. Illinois: A Test Is Finally Promulgated.................. 159

H. United States v. Ceccolini: Attenuation Takes a Different Turn 160

I. Dunaway v. New York: Repeating Brown

J. Rawlings v. Kentucky: Giving Meaning to the Brown Factors

K. Segura v. United States: Undermining the Causal Argument 164

L. New York v. Harris: Another Vehicle for Attenuation Discussion 164

M. Kaupp v. Texas: Drifting Backwards .................................. 166

N. Hudson v. Michigan: Jettisoning the Brown Approach ....... 166

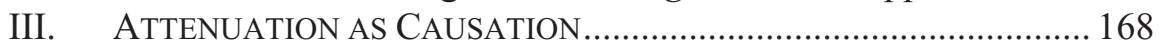

A. But-For Causation .......................................................... 170

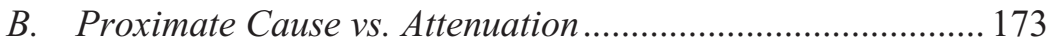

C. Brown and Defining Attenuation ............................................ 175

1. Temporal Proximity .......................................................... 175

2. Intervening Event......................................................... 176

3. Purpose and Flagrancy of Police Action......................... 181

IV. NON-CAUSAL USES OF ATTENUATION ......................................... 185

A. The Interests Being Served Approach ................................... 186

B. Attenuation and Foreseeability............................................ 187

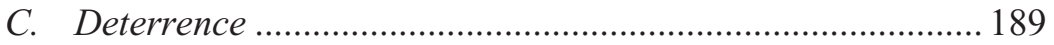

V. RESTORING CAUSATION TO ATTENUATION ................................... 195

A. Limiting Attenuation to Those Occasions When We Evaluate an Independent Act of Free Will ............................................ 196

B. Limiting the Definition of Intervening Events ....................... 197

C. Remove Test Three from Brown .......................................... 198

D. A Totality Approach ...................................................... 200

VI. CONCLUSION ................................................................... 201 


\section{INTRODUCTION}

In courts across every state and federal jurisdiction in the country on a weekly, if not daily, basis, judges are confronted with similar basic questions regarding the relationship between police conduct and the evidence discovered as a consequence of this conduct. Controversy arises when the police act in ways contrary to the Fourth Amendment of the United States Constitution and improperly search the property of an individual or seize his person. ${ }^{1}$ Often, the controversy is exacerbated by the subsequent discovery by the police of very incriminating evidence of guilt. Judges are then asked the simple, but fundamental, question of whether the evidence discovered was a product of unconstitutional police conduct. Another way of stating the question is - did the police conduct cause the discovery of the evidence? If the answer is yes, then the discovery of the evidence is also a Fourth Amendment violation, and the judge is then forced to decide what to do about it.

In most cases, the question of cause is rather easy to answer. If the police officer unconstitutionally arrests a suspect, searches his person, and discovers illegal drugs, it is easy for the court to conclude that the evidence was the product of an unconstitutional arrest and that the arrest caused the discovery of the evidence. Unfortunately, for trial courts throughout the country, not all questions of causation are so easily answered. What happens if, after the same illegal arrest, the suspect consents to a search of his person and illegal drugs are discovered. Or, after the same illegal arrest, the suspect confesses to a crime. Is the evidence discovered following the consensual search a product of the original Fourth Amendment violation? Is the confession a product of the unconstitutional arrest? These situations of indirectly discovered evidence have vexed our courts for decades.

Part of the reason these situations are difficult is simply because, factually, it is hard to tell if the consent or confession is due to the conduct of the police or to something else. Maybe it is the consequence of cost/benefit analysis by a carefully calculating criminal, or maybe advice of counsel, or deep guilt, or a combination of all of these factors. However, it may just as easily be due to the illegal arrest and nothing else. While we all have common sense instincts as to what may have motivated the suspects conduct, it is never objectively obvious. These cases are also difficult because, when we assess causal responsibility to police misconduct for indirectly discovered evidence, we are dramatically expanding the scope of situations in which courts have to decide what to do about the incriminating evidence. Perhaps, we might argue, by extending the causal chain so far, we are forcing decisions about evidence that we do not wish to make. Whether the conduct of officer A caused the eventual discovery of evidence B may not be as important — from a policy perspective — as whether we

$1 \quad$ U.S. CONST. amend. IV. 
wish to make A responsible for $\mathrm{B}$, with all the consequences that this carries with it. $^{2}$

This fear of consequence has resulted in a United States Supreme Court jurisprudence that has struggled to separate the causal question from the policybased consequences that flow from the causal conclusion. Given that the primary remedy for evidence seized as a consequence of a Fourth Amendment violation has been to exclude the evidence from any subsequent criminal proceeding, the stakes are certainly high. ${ }^{3}$ The Supreme Court, never greatly enamored with the exclusionary rule, ${ }^{4}$ has seen manipulation of the underlying causal question as a means of limiting the reach of the exclusionary rule. Thus, the Court has created and expanded on the concept of attenuation. Attenuation is the simple proposition that sometimes the evidence is too far removed from the original police misconduct to allow for a conclusion that the misconduct caused the discovery of the evidence. ${ }^{5}$ The Supreme Court has attempted to flesh out this basic causal concept but has often done more to confuse than clarify attenuation and its applicability.

Commentators have not always helped in preserving the logic and simplicity of attenuation. Analogies to tort law and proximate cause have simply undermined the basic causal nature of attenuation. Proximate cause is a policybased concept. ${ }^{6}$ The advocates of analogizing attenuation with proximate cause are, thus, suggesting that questions of the causal reach of a particular action are best informed by what we wish for the outcome to be rather than what causality tells us it is. When the overwhelming desire is to admit this indirectly discovered evidence, the driving force in the analysis is no longer causality based on fact, but outcomes based on policy. These proponents of attenuation as policy, as a commentator on an altogether different topic so aptly put it, "were neither stupid or operating in bad faith ... their logical reasoning was subordinated to dogmatic first principles." This first principle — avoiding the exclusionary rule at any

2 See H. L. A. Hart \& A. M. Honoré, Causation In The Law 88 (1959) (noting that "[j]udges may simply choose not to refer to causal language to rules limiting liability out of considerations of policy or convenience").

$3 \quad$ See Mapp v. Ohio, 367 U.S. 643 (1961).

$4 \quad$ See Herring v. United States, 555 U.S. 135, 141 (2009) (where the Court observed that the exclusionary rule allows "guilty and possibly dangerous criminals to go free" with the consequence that the toll imposed by the rule is, in fact, a high obstacle to its use).

5 See Brown v. Illinois, 422 U.S. 590, 591 (1975); Wong Sun v. United States, 371 U.S. 471, 490 (1963).

$6 \quad$ See, e.g., Palsgraf v. Long Island R.R. Co., 162 N.E. 99, 103 (N.Y. 1928) (Andrews, J., dissenting). Justice Andrews, in his famous dissent, states that proximate cause means that "because of convenience, of public policy, of a rough sense of justice, the law arbitrarily declines to trace a series of events beyond a certain point." Id. He further observes, "[T] his is not logic. It is practical politics."

Tony Judt \& Timothy Snyder, Thinking The Twentieth Century 319 (2012). 
cost - has undermined the concept of attenuation and created a muddled approach to a fairly straightforward causal concept.

In this Article, it will be argued that the best solution to this problem would be to return attenuation to its true origins as a means of examining if a causal link between original police misconduct and subsequently discovered incriminating evidence exists. By reexamining the tests we use to assess attenuation, limiting the applicability of the principle to only certain types of indirectly discovered evidence, redefining certain factors that must be considered, and suggesting a common sense way to put it all together, this Article will attempt to restore causality to attenuation. In Part II, we will engage in a short history of the attenuation concept, particularly as addressed by the United States Supreme Court. In Part III, this Article will set forth the arguments for why attenuation is best seen as a causal concept and functions best as a purely causal measure. In Part IV, we will examine the ways in which attenuation has been diluted as a causal concept by a Supreme Court focusing on other, noncausal, objectives. Finally, in Part V, this Article will set forth the ways by which the concept of attenuation can be redefined and limited so as to accentuate the causal attributes of the concept and limit the non-causal objectives that have drifted in over time.

The most important question may be why this matters. Why is it important to limit our discussions of attenuation to a causal mechanism to examine the linkage between Fourth Amendment violations and subsequently discovered evidence? Primarily to preserve the utility and integrity of the concept. Causation is fact based. It does not change over time - no logical determination does. The ebb and flow of the policy debates surround the exclusionary rule are immaterial to causation. When, however, attenuation is modified to address policy concerns we turn the concept into one which will be changed and modified (perhaps forever) by a Court that struggles to address the consequences of Fourth Amendment violations when the evidence in question is clearly evidence of guilt. Fact finders - judges - in trial courts throughout this country need useful tests to establish causality. Today, attenuation is no longer such a test.

\section{A SHORT History OF ATTENUATION}

The following section will provide a brief history of attenuation through the lens of the most significant Supreme Court decisions which have addressed the concept. The reader should readily see the manner in which the concept has evolved through Supreme Court jurisprudence.

\section{A. Nardone v. United States: Attenuation Is Born}

As is often the case, the concept of attenuation had a fairly obscure birth with no indication that it would grow up and attain the significance it has. The first reference to the concept was in the Supreme Court decision of Nardone $v$. 
United States. ${ }^{8}$ There, in a follow-up to a previous case ${ }^{9}$ involving the use of illegally intercepted telephone messages, the Court examined the legality of the government's use of these messages to obtain other incriminating evidence against the defendant. ${ }^{10}$ The Court went through a fairly simple process of analysis and concluded that, consistent with Silverthorne Lumber Co. v. United States, ${ }^{11}$ the federal statute in question - the Communications Act of 1934prohibited any use of the illegally obtained materials, even if the use was derivative. The Court did not stop there, however. Writing for the majority, Justice Frankfurter went on to describe situations in which this prohibition would not apply. First, he noted that if the information used was "gained from an independent source" it would not matter that the illegally obtained information would also have led to the information in question. ${ }^{12}$ This argument is consistent with the subsequently elaborated exception to the Fourth Amendment exclusionary rule known as the "independent source" doctrine. ${ }^{13}$

Frankfurter went further than this, however. In a somewhat throwaway portion of the opinion, he noted, "[s]ophisticated argument may prove a causal connection between information obtained through illicit wire-tapping and the Government's proof. As a matter of good sense, however, such connection may have become so attenuated as to dissipate the taint." 14 From such humble beginnings the doctrine of attenuation was born.

It is interesting to note several aspects of this brief reference. First, the Nardone case was not one dealing with the Fourth Amendment at all. Rather, it was a case interpreting statutory prohibitions on government wiretapping. ${ }^{15}$ Thus, nothing in the case suggests that the concept of attenuation was intended to be directly linked to the Fourth Amendment or the exclusionary rule. Second, it could be argued that the statement is mere dicta. Nothing in the case required the court to opine on any exception to the basic rule that information obtained from an illegal wiretap could not be used - even derivatively. The government certainly never advanced such an argument. Finally, Justice Frankfurter does suggest that his concept of attenuation is a necessary counter to the "causal argument" which might link the illegally obtained information from subsequent proof offered by the government. ${ }^{16}$ This injects causality into the equation and

\footnotetext{
$8 \quad$ Nardone v. United States (Nardone II), 308 U.S. 338 (1939).

$9 \quad$ Nardone v. United States (Nardone I), 302 U.S. 379 (1937).

$10 \quad$ Nardone II, 308 U.S. at 340.

11251 U.S. 385, 392 (1920).

$12 \quad$ Nardone II, 308 U.S. at 341.

13 See Nix v. Williams, 467 U.S. 431 (1984).

$14 \quad$ Nardone II, 308 U.S. at 341.
}

15 See Tracy Maclin, The Supreme Court and the Fourth Amendment’s ExClusionary Rule 34 (2013).

$16 \quad$ Nardone II, 308 U.S. at 341. 
suggests that attenuation was always intended to be a concept framed by basic causal analysis. Nothing in Nardone suggests attenuation is at all tied to remedies such as the Federal exclusionary rule that had been established in Weeks $v$. United States. ${ }^{17}$

\section{B. Costello v. United States: Still an Amorphous Concept}

Attenuation next surfaces in a significant way in Costello v. United States. ${ }^{18}$ In Costello, the Court makes a passing reference to attenuation in a way that suggests it has yet to be viewed as a stand-alone concept with anything approaching a clear definition. The defendant in Costello objected to the government's use of incriminating statements he made to government officials subsequent to an illegal wiretap on his phone. ${ }^{19}$ Costello contended that these incriminating statements were the product of the illegal wiretaps. ${ }^{20}$ The Supreme Court rejected the argument, contending that the information obtained from Costello was, in fact, obtained from an "independent source." ${ }^{21}$ The Court went on to cite in its entirety Justice Frankfurter's statement on attenuation found in Nardone. ${ }^{22}$ The Court then held that the incriminating statements given by Costello were the consequence of an independent source and "that any connection between the wiretaps and the admissions was too attenuated to require the exclusion of the admissions from evidence." 23 One of two conclusions can be drawn from this brief reference. Either the Court believes that attenuation and "independent source" are essentially the same thing or, if it does recognize them as completely separate concepts, the Court was not prepared to provide any means by which to determine if attenuation had taken place. At this stage, attenuation was still an amorphous concept with no clear tests to suggest when, or if, it applied.

\section{Wong Sun v. United States: Attenuation Comes to Life}

Attenuation only really begins to come to life in the Court's 1963 decision in Wong Sun v. United States. ${ }^{24}$ In that case, after unlawful entry into one defendant's home and several arrests without probable cause, two defendants

232 U.S. 383 (1914). See also MACLIN, supra note 15, at 17.

365 U.S. 265 (1961).

Id. at 278 .

Id.

Id. at 280 .

Id.

Id.

371 U.S. 471 (1963). 
gave incriminating statements. ${ }^{25}$ The first defendant, James Wah Toy, made incriminating statements in his bedroom shortly after the police had forced their way into the room and arrested him. ${ }^{26}$ The Government argued that the statement should still be admissible - despite the claim that it was the "fruit of the poisonous tree"-because it was the product of "an intervening act of free will." ${ }^{27}$ The Court, however, dismissed this argument, asserting that, under the circumstances, "it is unreasonable to infer that Toy's response was sufficiently an act of free will to purge the primary taint of the unlawful invasion." ${ }^{28}$ Wong Sun's situation was different, however. Wong Sun was illegally arrested, but he declined to sign the incriminating statement he made to the police on the day of his arrest. ${ }^{29}$ After Wong Sun was released, he voluntarily returned to the police station several days later and made an incriminating statement. ${ }^{30}$ The Court concluded that this statement was admissible because "the connection between the arrest and the statement had 'become so attenuated as to dissipate the taint." "31 The Court specifically pointed to the fact that Wong Sun had been released and had returned voluntarily after the lapse of several days to make the incriminating statement. ${ }^{32}$

What we can conclude from Wong Sun is that the concept of attenuation was still rather undeveloped at this point. A lapse of over 25 years between Nardone and Wong Sun had not seen the concept of attenuation used in any meaningful way by the Supreme Court. However, Wong Sun does give us some hints as to what attenuation might mean..$^{33}$ Attenuation must mean that something has taken place which purges the taint that the unlawful conduct of the police has cast upon the evidence in question. Wong Sun implies that attenuation is a factual inquiry to determine if something occurred in the case in question that would have the effect of purging the taint.$^{34}$ In the case of the defendant Toy, the Court discussed physical evidence (drugs) that was obtained as a consequence of Toy's statements. ${ }^{35}$ The Court excluded this evidence as well as Toy's statements because the evidence was not obtained in a manner that would indicate that the

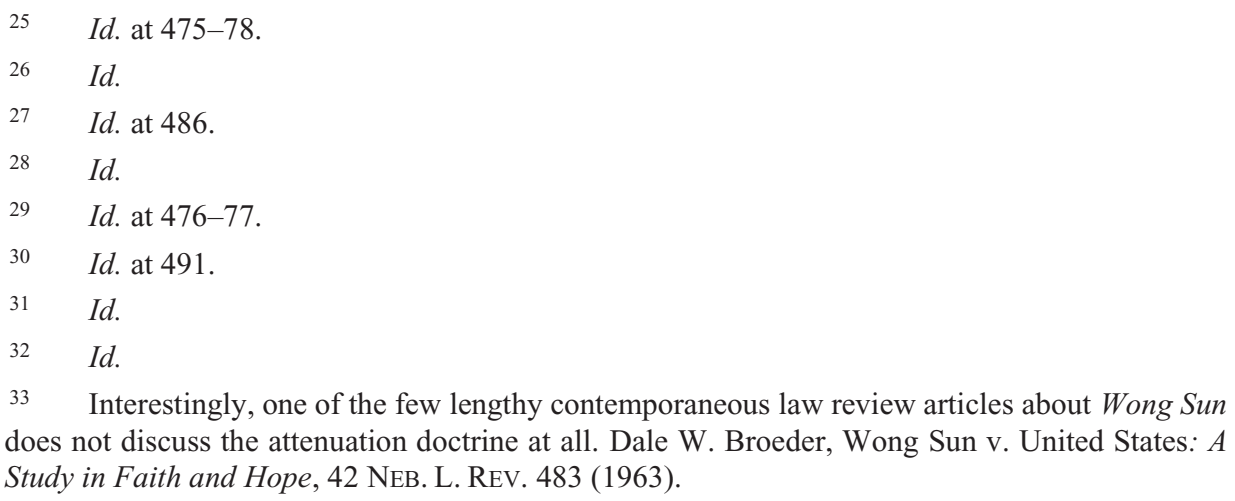

$35 \quad$ Id. at 487. 
taint of the illegal conduct had somehow been removed. ${ }^{36}$ As the Court observed, "the more apt question in such a case is "whether, granting establishment of the primary illegality, the evidence to which instant objection is made has been come at by exploitation of that illegality or instead by means sufficiently distinguishable to be purged of the primary taint." 37 This is fundamentally and exclusively a factual question - nothing about it has anything to do with the appropriate remedy should the taint of the police misconduct attach to the subsequently discovered evidence. Attenuation would arise when the incriminating evidence was obtained as a result of a combination of facts that would indicate that the acquisition of the evidence was not the simple consequence of police misconduct, but rather was somehow distinguishable from the original illegality - in other words, something else caused the confession subsequently made by the defendant. In the case of Wong Sun, those facts were the lapse of time between the illegality and the incriminating evidence and the voluntary choice made by the defendant to make the statement. ${ }^{38}$ The Court seems to be saying that the acquisition of the evidence in this situation had more to do with Wong Sun and the choices he made after deliberation than it had to do with the illegal nature of his original arrest. Fundamentally, this is a question of causation. What caused Wong Sun to make the statements that he did? The Court concludes that, whatever it might have been, it was not simply because he was illegally arrested. ${ }^{39}$

\section{Harrison v. United States: The Beginning of the Confusion}

The first significant step towards the muddle we now find ourselves in with respect to attenuation can be found in Justice White's dissent in Harrison $v$. United States only five years later. ${ }^{40}$ There, Justice White criticizes the way the Court interpreted the concept of fruit of the poisonous tree. ${ }^{41}$ White claims that the Court has engaged in an overly simplistic assessment of the poisonous tree concept which, in the end, was a focus on "but-for" causation. ${ }^{42}$ White claims that this causal approach "rarely" excepts inculpatory evidence that occurs later in time - in other words, it is very easy to say that nearly all evidence found after illegal police conduct was "caused" by the illegal conduct. ${ }^{43}$ Then White drops his bombshell:

$\begin{array}{ll}36 & \text { Id. at } 487-88 . \\ 37 & I d . \text { at } 488 . \\ 38 & I d . \text { at } 491 . \\ 39 & \text { Id. } \\ 40 & \text { 392 U.S. } 229 \text { (1968) (White, J., dissenting). } \\ 41 & I d . \text { at } 230-31 . \\ 42 & I d . \\ 43 & I d .\end{array}$


[M]ere causal connection is insufficient to make something an inadmissible fruit. Rather it must be shown that suppression of the fruit would serve the same purpose as suppression of the illegal evidence itself . . . the reason for the suppression of the original illegal evidence itself is prophylactic - to deter the police from engaging in such conduct in the future by denying them its past benefits. Since deterrence is the only justification for excluding the original evidence, there is no justification for excluding the fruits of such evidence unless suppression of them will also serve the prophylactic end. ${ }^{44}$

White acknowledged the limitations placed on the fruits analysis by attenuation and favorably cites Nardone and Wong Sun. But then he throws it all away. White's focus is on remedy, not causation..$^{45}$ The extent to which he and subsequent justices confuse these concepts when discussing and defining attenuation is at the core of the problems that we currently face.

\section{E. United States v. Giordano: A Brief Reference to Attenuation}

Aside from the White dissent in Harrison, the only other significant development in the attenuation doctrine in Supreme Court jurisprudence-prior to the blockbuster decision in Brown v. Illinois ${ }^{46}$ - is a brief reference to the doctrine in United States v. Giordano. ${ }^{47}$ There, in a concurrence drafted by Justice Powell, four members of the court suggested that attenuation was closely tied to the presence or absence of an intervening factor. As the concurrence notes, "the derivative taint of illegal activity does not extend to the ends of the earth but only until it is dissipated by an intervening event." 48 This is a fairly categorical conclusion which only goes to illustrate how little thought had actually been given to the attenuation doctrine and the implications of Wong Sun. Clearly, Wong Sun suggested that lapse of time might be an important factor in evaluating the presence or absence of attenuation. ${ }^{49}$ Yet, the concurring justices in Giordano, including Justice Brennan-the author of the Wong Sun opinionsaid nary a word about lapse of time. ${ }^{50}$

It is useful to look at the broader legal landscape when exploring the meaning of attenuation after Wong Sun but before Brown. It may be the case that Federal and State courts had more expansively examined the concept and had,

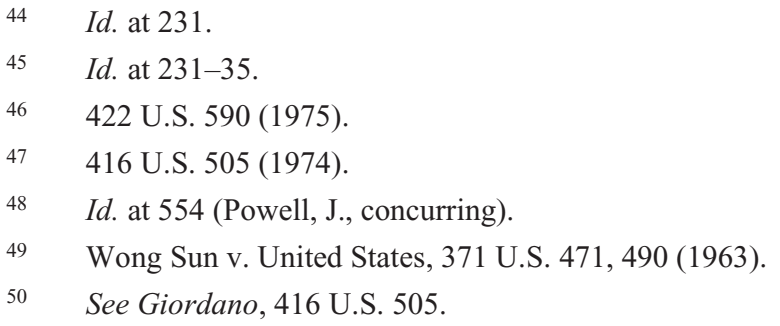


perhaps, found ways to implement it in a factually rich way. Broadly speaking, it is first worthy of note that there were fairly few cases invoking the attenuation doctrine decided by the federal circuit courts or state supreme courts from 1963 to 1975 . In neither the federal nor state courts were there more than a dozen reported cases that dealt in depth with the concept. Starting with the federal courts, we can say, for the most part, that the circuit courts saw attenuation as a causality issue first and foremost $\mathrm{t}^{51}$ — with only two or three who even mentioned linking the concept to remedy and the deterrent goals of the exclusionary rule. ${ }^{52}$

The federal courts during this time frame also took a stab at identifying factors that would make attenuation more or less likely. Moving beyond the broad focus on lapse of time or an "intervening event," these courts looked at more specific things such as "the voluntary act of appellant's going to the car and exposing its contents" to the police, ${ }^{53}$ or the fact that the suspect decided to cooperate with the police after consulting with a lawyer who brought him, voluntarily, to the courthouse to confess. ${ }^{54}$ When assessing whether the testimony of a witness that was discovered through illegal police conduct should be excluded, the Fifth Circuit Court of Appeals suggested looking at "[p]roof that the witness would have come forward by his own volition, regardless of his identification by the illegal search" (suggesting attenuation) and "evidence that the witness was completely uncooperative when originally discovered by the illegal search but later changed his attitude and supplied the necessary information" (also suggesting attenuation). ${ }^{55}$ These cases all suggest that what may be important is not just an intervening event, but one which suggests voluntary cooperation with the police. This voluntary cooperation could be the result of any number of factors, but at root, this type of event establishes a causal break from the original illegality. The subsequent actions by the suspects were motivated not by the original police conduct, but by other things - some known and some unknowable. ${ }^{56}$ This is a purely causal approach and is consistent with the view that extending the scope of a Fourth Amendment violation should be primarily driven by causality.

$51 \quad$ E.g., United States ex rel. Owens v. Twomey, 508 F.2d 858, 865 (7th Cir. 1974).

$52 \quad$ See Parker v. Estelle, 498 F.2d 625 (5th Cir. 1974); Durham v. United States, 403 F.2d 190 (9th Cir. 1968).

53 Agius v. United States, 413 F.2d 915, 919 (5th Cir. 1969).

$54 \quad$ Parker, 498 F.2d at 630.

$55 \quad$ United States v. Marder, 474 F.2d 1192, 1196 (5th Cir. 1973).

56 As the Court in Parker observed, "Can we say that the pressure of the confession must have dominated [the witness's] conscience to cause him to change his story? In this outreach of the exclusionary rule, we decline Parker's invitation to speculate on the imponderables of human will and motivation." Parker, 498 F.2d at 630. 


\section{F. Agius v. United States: Other Factors to Consider}

These few federal decisions also suggested other things that might matter when assessing attenuation. For example, in Agius v. United States, the court suggested the conduct of the police might matter in deciding whether subsequently discovered incriminating evidence was attenuated from prior, illegal police conduct. ${ }^{57}$ As the Court observed, "[t]here was no intimidation, trickery, or cajolery, and the agents in no way induced or caused appellant to expose the contents of his car." ${ }^{58}$ Why would this matter? Perhaps - sticking to a causal approach - it would be important in assessing the "voluntary" nature of the intervening event that ostensibly severed the causal chain. Importantly, in light of what would come later in Brown, the court seemed to focus on police conduct after the initial illegal custodial interrogation, not the police conduct during the illegal interrogation..$^{59}$

Several state supreme courts also addressed the issue of attenuation between the Wong Sun decision and the later decision in Brown. While the number of these cases was less than a dozen, these state courts still wrestled with formulating some sort of test for attenuation and with placing attenuation into some sort of jurisprudential framework. Some courts readily conceded that attenuation was a causal concept. As the Pennsylvania Supreme Court observed, common sense allows us to find the presence or absence of "but-for" causation. ${ }^{60}$ The more difficult question is that of "proximate cause." As this court noted, it is important to explore the causal explanation for the discovery of the subsequent incriminating evidence. In this case, a witness, who was illegally arrested and questioned after an illegal search of the defendant's residence, subsequently voluntarily pled guilty and testified against the defendant. As the Court noted, " $[t]$ he primary question ... when dealing with the taint issue, . . , is not whether the witness voluntarily pled guilty and testified, rather it is Why she chose to do this." ${ }^{61}$ The "why" question is a causal question and only makes sense in that light.

Other state courts offered factors to consider when looking for the presence of attenuation. The California Supreme Court found that the taint of illegal police conduct could be removed if there was "an intervening independent act by the defendant or a third party which breaks the causal chain linking the illegality and the evidence." ${ }^{62}$ The Court further noted that consent by the

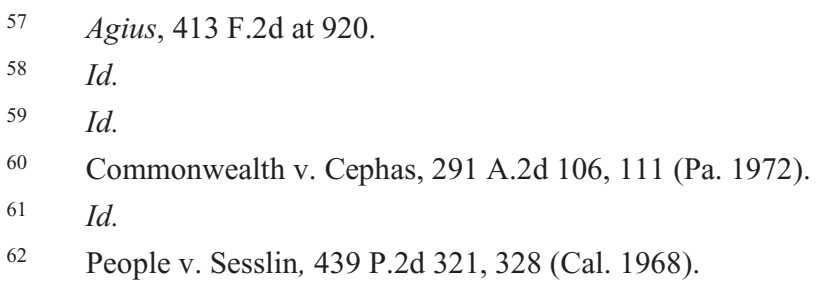


defendant could be such an intervening act if it were an act of free will. ${ }^{63}$ In a similar vein, the Pennsylvania Supreme Court focused on the lapse of time between the offending police action and the subsequently discovered incriminating evidence. ${ }^{64}$ The Court concluded that a lapse of time of only thirty minutes precluded a finding of attenuation. ${ }^{65}$

\section{G. Brown v. Illinois: A Test Is Finally Promulgated}

Ultimately, it was left to the Supreme Court to place more definitive parameters upon the way that attenuation was to be evaluated. These parameters were articulated in Brown v. Illinois. In Brown the defendant was arrested without a warrant and without probable cause ${ }^{66} \mathrm{He}$ was provided the warnings mandated by Miranda v. Arizona ${ }^{67}$ and then made two inculpatory statements to the police. ${ }^{68}$ The primary focus of the case was whether the inculpatory statements were attenuated from the illegal arrest because of the Miranda warnings. ${ }^{69}$ The Court ultimately concluded that providing the Miranda warning was not enough to, in and of itself, attenuate the inculpatory statements from the police misconduct. ${ }^{70}$ Attenuation and the exclusionary rule are Fourth Amendment concepts, and the provision of Miranda warnings - and the exclusion or confessions obtained without these warnings-address Fifth Amendment concerns.

For our purposes, however, the decision is far more important for the way in which it establishes a test by which to assess attenuation. The Court acknowledged that the objective of the attenuation doctrine was to ensure that the cause of subsequently incriminating evidence was not the prior illegal conduct of the police. ${ }^{71}$ As the Court observed, the focus must be on whether the incriminating conduct of the defendant was "sufficiently a product of free will . . . [to] break, for Fourth Amendment purposes, the causal connection between the illegality and the confession." 72 The difficulty is deciding when this has occurred. The Court observed, first of all, that such a determination is a factual one that varies from case to case. ${ }^{73}$ The Court then asserted that constructing a

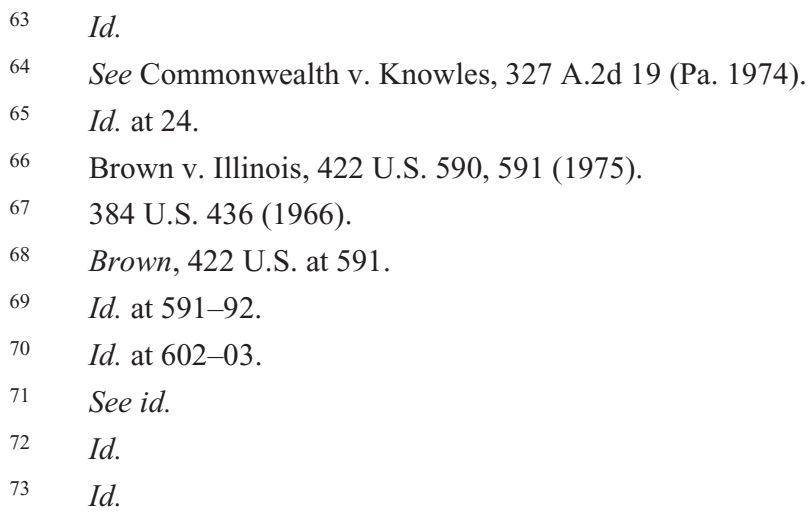


test to govern these situations is not easy. "The workings of the human mind are too complex, and the possibilities of misconduct too diverse, to permit protection of the Fourth Amendment to turn on . . . a talismanic test." "74

The Brown Court then proceeds to set forth three factors, in addition to the presence or absence of Miranda warnings, which courts should consider when attempting to decide if subsequent incriminating evidence, such as a confession, was obtained as a causal product of prior illegal police activity. ${ }^{75}$ Courts should focus on the "temporal proximity of the arrest and the confession, the presence of intervening circumstances, and, particularly, the purpose and flagrancy of the official misconduct." elaboration or explanation of these factors. With respect to the third factor, the purpose and flagrancy of the official misconduct, however, the Court did elaborate. Specifically, the Court observed that in the Brown case, there was an element of "purposefulness" in the police misconduct - suggesting that the illegal steps taken by the police were in the "hope that something might turn up." 77 Beyond that, the Court gave no guidance as to how to evaluate or weigh the factors suggested nor did it indicate that these tests were designed to get to the question of causality - or anything else, for that matter. Brown thus gave the concept of attenuation greater substance than prior cases had, but failed to articulate a tight, workable test.

\section{H. United States v. Ceccolini: Attenuation Takes a Different Turn}

The attenuation doctrine took a different turn in the 1978 Supreme Court decision in United States v. Ceccolini. ${ }^{78}$ In Ceccolini, an illegal police search led to the discovery of illegality and this discovery led the police to obtain the testimony of a witness who was not aware of the illegal conduct in question. ${ }^{79}$ The District Court suppressed the witnesses testimony because the prosecution could not show that they would have discovered the witness without the illegal police conduct. The majority set forth a different test for evaluating live-witness testimony that resulted from police illegality. The Court asserted that reviewing courts should focus on the free will exercised by the witness and the witness's willingness to testify. ${ }^{80} \mathrm{~A}$ willing witness's testimony is more likely the product of considered reflection and a desire to be cooperative, and "the illegality which led to the discovery of the witness very often will not play any meaningful part

$\begin{array}{ll}74 & I d . \\ 75 & I d . \text { at } 601-04 . \\ 76 & I d . \text { at } 603-04 . \\ 77 & I d . \text { at } 605 . \\ 78 & \text { 435 U.S. 268 (1978). } \\ 79 & I d . \text { at 269-70. } \\ 80 & I d . \text { at 276. }\end{array}$


in the witness' willingness to testify." ${ }^{81}$ Secondly, reviewing courts should focus on the cost of excluding such testimony given that exclusion of such testimony would "perpetually disable a witness from testifying about relevant and material facts ...." ${ }^{82}$ The Court pointedly noted that attenuation analysis should focus on these facts when looking at live-witness testimony, but could focus on "different factors" with respect to "inanimate evidence." 83 This approach to live-witness testimony which results from police illegality is completely devoid of any reference to causality. Rather, while still ostensibly retaining the attenuation framework suggested in Brown, both factors suggested by the Court deal with non-causal concerns such as how much the witness really wanted to cooperate and how devastating the loss of such testimony might be. This approach does not view attenuation as a causal construct.

\section{Dunaway v. New York: Repeating Brown}

In Dunaway v. New York, ${ }^{84}$ the court confronted a situation nearly identical to that in Brown and reached a conclusion nearly identical to the Brown decision as well. The only real difference was the composition of the Court with Justice Douglas - in the majority in Brown - replaced by Justice Stevens. ${ }^{85}$ The caveats placed on attenuation in the Ceccolini decision were nowhere to be found, and the simple application of the Brown factors led to a straightforward conclusion that attenuation did not exist. The only interesting developmentfrom a causal perspective - was Justice Stevens' concurrence. There, Stevens first claimed that the temporal factor set forth in Brown could be viewed in a different way. ${ }^{86}$ In Brown, the Court concluded that when little time had elapsed between illegal police activity and a subsequent incriminating statement by the defendant, it was fair to conclude that there was a causal link between the two. ${ }^{87}$ In Dunaway, Stevens observed that "[t] he temporal relationship between the arrest and the confession may be an ambiguous factor." ${ }^{88}$ Stevens goes on to observe that sometimes prolonged detention may be a means to exploit an illegal arrest whereas a statement made rapidly after an illegal arrest may be the

\footnotetext{
$81 \quad$ Id. at $276-77$.

$82 \quad I d$. at 277.

83 Id. at $277-78$.

84442 U.S. 200 (1979).

85 Justices of the Supreme Court, 442 U.S. iii (1978) (available at https://tile.loc.gov/storageservices/service/11/usrep/usrep442/usrep442justices/usrep442justices.pdf).

86 Dunaway, 442 U.S. at 220 (Stevens, J., concurring).

87 Brown v. Illinois, 422 U.S. 590, 604-05 (1975).

88 Dunaway, 442 U.S. at 220 (Stevens, J., concurring).
} 
consequence of some other precipitating event, such as a prearrest "visit with a minister." 89

In addition, Stevens contended that the flagrancy of the police conduct may or may not be relevant in determining the link between the illegal arrest and the subsequent incriminating statement. ${ }^{90}$ Where Stevens is on board with the Brown decision is his belief that these factors are only designed to assist in assessing the causal relationship between the illegal activity of the police and the incriminating evidence that followed. As he stated, "the admissibility question will turn on the causal relationship between... [the] violation and the defendant's subsequent confession." ${ }^{\text {"1 }}$ In Stevens' view, the causality question was an objective question and pursuing objective criteria was preferable to a more subjective quest for an appropriate remedy. ${ }^{92}$

\section{J. Rawlings v. Kentucky: Giving Meaning to the Brown Factors}

Over time, the Brown factors were given additional meaning by the Supreme Court. In Rawlings v. Kentucky, ${ }^{93}$ the Court undertook an attenuation analysis and gave added meaning to the first Brown factor-the lapse of time between the illegal police conduct and the subsequent discovery of incriminating evidence. ${ }^{94}$ In Brown, the lapse of time factor had causal relevance insofar as the Court concluded that given a short lapse of time between illegal police conduct and an incriminating statement by the defendant, the statement would likely be causally attributed to the police conduct in question. ${ }^{95}$ In Rawlings, the Court held that lapse of time, in and of itself, was not enough to decide the causal question, however..$^{96}$ The defendant was detained at a house by police while they sought a warrant. ${ }^{97}$ While never deciding the question of whether the detention was illegal, the Court went on to examine the subsequent events from a Brown perspective. ${ }^{98}$ In particular, the Court examined the 45 minutes that elapsed between the alleged illegal detention and the defendant's incriminating statements. ${ }^{99}$ Acknowledging that the lapse of time might not be adequate to "purge the taint," the Court felt it necessary to evaluate that question in light of

Id. at $220-21$.

Id. at 220 .

Id.

Id. at 221 .

448 U.S. 98 (1980).

Id. at $107-08$.

Brown v. Illinois, 422 U.S. 590, 604-05 (1975).

Rawlings, 448 U.S. at 107.

Id. at 100 .

Id. at 110 .

Id. at 107 . 
"the precise conditions under which the occupants of this house were detained." 100 The Court then provided evidence to suggest that a "congenial atmosphere" existed within the house during the lapse of time. ${ }^{101}$ This congenial atmosphere, apparently, made all the difference insofar as the Court concluded that "these circumstances outweigh the relatively short period of time that elapsed between the initiation of the detention and the petitioner's admissions." 102 Why might this be the case, from a causal perspective? Perhaps this congenial atmosphere suggests that the coercive effect of the police action was undermined by the subsequent good feeling that existed between the police and the defendant. Such a conclusion would need to be based on a belief that the illegal police conduct must be subjectively understood by the suspect as opposed to objectively recognized after the fact. If a suspect subjectively understands that police misconduct has occurred but somehow "forgives" it as evidenced by a congenial atmosphere, then a subsequent incriminating statement could not be causally linked to the misconduct. Presumably, the misconduct was no longer a factor in motivating the suspect's conduct.

Proceeding on this path has grave dangers. Introducing a subjective element into any constitutional test is fraught with difficulty, particularly if the test is fact based. The Court, in nearly all matters pertaining to the Fourth Amendment, has preferred to stick to an objective test. ${ }^{103}$ In this case, concluding that the illegal police conduct didn't matter, despite the short lapse of time between the police conduct and the incriminating statement, depends upon a conclusion that the defendant subjectively was not influenced by the original police conduct because of the subsequent congenial atmosphere. Yet, in this case, that congenial atmosphere was established by the testimony of others in the house - not the defendant. ${ }^{104}$ It is impossible to know what, subjectively, he was feeling about the police and his detention. To suggest that the subsequent incriminating statement made by the defendant was not causally linked to his illegal detention because he seemed to be getting along with the police requires a degree of speculation which is anathema to causal analysis.

In many ways, the Brown tests are designed to allow for an objective assessment of causality. By examining lapse of time, intervening factors, and perhaps even the nature of police conduct, an objective observer of the sequence of events can reach a rational conclusion as to the causal linkage between the original police illegality and the incriminating evidence. If we intend to move beyond "but-for" causality to something more meaningful, we have to find a way

\footnotetext{
$100 \quad I d$. at 107.

$101 \quad I d$. at 108.

$102 \quad I d$.

103 See Whren v. United States, 517 U.S. 806 (1996); California v. Hodari D., 499 U.S. 621 (1991).
}

104 Rawlings, 448 U.S. at 108. 
of doing so that is objectively reasonable - even logical, if you will. We can never know if the illegal act actually caused the subsequent discovery of incriminating evidence. We can never know for sure if the illegal act actually caused the suspect to make an incriminating statement. The best we can do is objectively examine the facts with the Brown factors in mind and reach a logical assumption. By interjecting subjectivity into the equation, Rawlings makes that assumption much less reliable.

\section{K. Segura v. United States: Undermining the Causal Argument}

The strength of the causality justification for the attenuation doctrine was unexpectedly placed in jeopardy by a dissent in the case of Segura v. United States. ${ }^{105}$ In Segura, the majority undertook a brief attenuation examination of facts surrounding an illegal seizure of a house and a subsequent search warrant that uncovered incriminating evidence. ${ }^{106}$ The majority opinion, drafted by Chief Justice Burger, revealed no new arguments pertaining to attenuation, toed the line on the causal nature of attenuation, and in fact based this portion of its opinion on the independent source doctrine more than any attenuation conclusion. ${ }^{107}$ The dissent, authored by Justice Stevens and joined by Justice Brennan, Marshall, and Blackmun, while disagreeing with the majority's conclusion, seems to significantly undermine the causal argument attached to attenuation. As the dissenters, including the very author of the Brown decision, note, "taint questions do not depend merely on questions of causation; causation is a necessary but not a sufficient condition for exclusion. In addition, it must be shown that exclusion is required to remove the incentive for the police to engage in the unlawful conduct." 108 This argument, in which the remedy appropriate for such Fourth Amendment violations overrides the logic governing the actual determination of the violation, is very harmful to the causal argument. No longer is causation - based on logic - the determining factor for issues of "taint." Now, fact-based causation starts the conversation, but the policy-based factor of deterrence makes the final call. One wonders if this was a conscious choice by the dissenters or simply a device to attack the result reached by the majority in Segura.

\section{New York v. Harris: Another Vehicle for Attenuation Discussion}

A subsequent case, New York v. Harris, ${ }^{109}$ was a vehicle for further discussion of the attenuation principle. The case involved an illegal entry by the

$\begin{array}{ll}105 & 468 \text { U.S. 796, } 817 \text { (1984) (Stevens, J., dissenting). } \\ 106 & \text { Id. at 798-99. } \\ 107 & \text { Id. at } 815 . \\ 108 & \text { Id. at } 830 \text { (Stevens, J., dissenting). } \\ 109 & \text { 495 U.S. } 14 \text { (1990). }\end{array}$


police into the defendant's home, his subsequent arrest, and several follow-on statements to the police. The police had probable cause to arrest the defendant but did so while illegally in his home. At issue was an incriminating statement made by the defendant at the police station. The majority held that this was not a situation for which Brown should even apply because, at the time the statement was made, the defendant's custody was not unlawful. ${ }^{110}$ As the Court noted, "attenuation analysis is only appropriate where, as a threshold matter, courts determine that "the challenged evidence is in some sense the product of illegal government activity.","111

While there was clearly illegal government activity, the Court concluded that the statements made subsequently were not a product of that entry, and thus not subject to attenuation analysis. But surely this begs the question. The purpose of attenuation analysis is to answer the very question of whether the incriminating statement was the product of the illegal entry. The majority, by means of a policy determination, answer that question. As it noted:

[W]e decline to apply the exclusionary rule in this context because the rule [in Payton $v$. New York prohibiting an arrest inside a home without a warrant] was designed to protect the physical integrity of the home; it was not intended to grant criminal suspects, like Harris, protection for statements made outside their premises where the police have probable cause to arrest the suspect for committing a crime. ${ }^{112}$

This conclusion has nothing to do with causation or attenuation. Justice Marshall, in his dissent, clearly illustrates the lack of causal analysis in the majority position. ${ }^{113}$ The Court, Marshall claims, set forth a per se rule that concludes categorically that a Payton violation cannot be causally connected to subsequent incriminating statements. ${ }^{114}$ As Marshall observes, "[n]either logic nor precedent supports that conclusion." 115 Rather, as Marshall notes:

[the] question cannot be answered with a set of per se rules. An inquiry into whether a suspect's statement is properly treated as attributable to a Fourth Amendment violation or to the suspect's independent act of will has an irreducibly psychological aspect,

$\begin{array}{ll}110 & I d . \text { at } 19 . \\ 111 & I d . \\ 112 & I d . \text { at } 17 . \\ 113 & I d . \text { at } 28 \text { (Marshall, J., dissenting). } \\ 114 & I d . \text { at } 26 . \\ 115 & I d . \text { at } 27 .\end{array}$


and irrebuttable presumptions are peculiarly unhelpful in such a context. ${ }^{116}$

Only by looking at each situation and closely analyzing the impact of the illegal police activity on the subsequent incriminating conduct of the defendant - as encouraged by the approach in Brown - may we clearly come to grips with the attenuation question. The question must be, did "the arrest [cause] the statement?"117

\section{Kaupp v. Texas: Drifting Backwards}

The Supreme Court seemed to drift back into a more fact-based analysis of causation over ten years later in Kaupp v. Texas. ${ }^{118}$ There, confronted with an attenuation question, the Court recited the familiar refrain that, "well-established precedent requires suppression of the confession unless that confession was 'an act of free will [sufficient] to purge the primary taint of the unlawful invasion." "119 More importantly, the Court goes on to assert that, "[d]emonstrating such purgation is, of course, a function of circumstantial evidence, with the burden of persuasion on the state." ${ }^{120}$ Accepting the factual nature of the analysis - as opposed to a per se rule approach - the Court then goes on to apply the factors in Brown to the situation in question. ${ }^{121}$ This clearly is a causal approach driven by facts and the inferences that arise from them.

\section{N. Hudson v. Michigan: Jettisoning the Brown Approach}

Yet, only three years later in Hudson v. Michigan, ${ }^{122}$ the court seemed to completely jettison the Brown approach. In Hudson, the police failed to observe the knock-and-announce policy that had governed the execution of warrants for hundreds of years. ${ }^{123}$ The question became whether the evidence seized as a consequence of the subsequent search should be excluded as the product of the knock-and-announce violation. The case certainly had a great deal of causal analysis ramifications - and ambiguities. The majority asserts that even if the police conduct here were a "but-for" cause of discovering the contraband in question, the attenuation doctrine would negate the causal relationship between

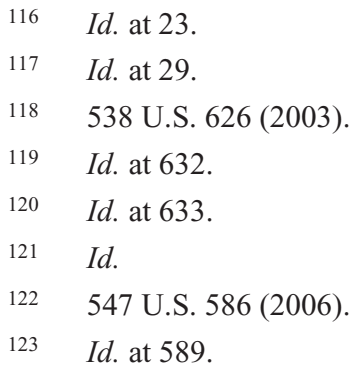


the two. ${ }^{124}$ Yet, the measure of attenuation used by the majority is novel and depends little upon the Brown approach. The majority asserts that attenuation can occur "when the causal connection is remote." 125 That is the end of the causal approach to attenuation. The majority focuses most of its attenuation analysis on the claim that attenuation also occurs - even when there is but-for causationwhen "the interest protected by the constitutional guarantee that has been violated would not be served by suppression of the evidence obtained." 126 Relying upon the reasoning in New York v. Harris,${ }^{127}$ the Court asserts that the purpose of the knock-and-announce rule is not to shield people from illegal searches, but rather to protect home residents and the police from the violence that might result from an abrupt entry into a home. ${ }^{28}$ Thus, excluding evidence obtained from an improper entry into the house doesn't really address the concerns of the knock-and-announce rule.

While it is difficult to argue with the Court's reasoning on this point, it does not really constitute an "attenuation" argument. It is a policy-based argument that has nothing to do with the causal link between the illegal police conduct and the subsequent discovery of incriminating evidence. Attenuation should always be viewed as a causal concept. As such, the only question becomes whether the circumstances are such as to suggest that the illegal police activity did not (really) cause the subsequent discovery of the incriminating evidence. The majority blurs the purpose of attenuation with this new approach. What is surprising is that, only a few pages later, the majority acknowledges that attenuation is different from the need for the deterrent value of exclusion to outweigh the costs. ${ }^{129}$ As the Court states, "[q]uite apart from the requirement of unattenuated causation" the exclusionary rule has not been applied when the deterrent value outweighs the social cost. ${ }^{130}$ Linking attenuation with causation in this statement seems to undermine the majority's own conclusion that attenuation is also a policy-based determination pertaining to the underlying purpose of the constitutional protection.

This confusion is exacerbated by Justice Kennedy's concurrence. Focusing solely on causation and ignoring remedy, Justice Kennedy concludes that the subsequent discovery of the incriminating evidence was too attenuated because failing to pause for 20 seconds cannot cause the discovery of evidence

\footnotetext{
$124 \quad I d$. at 592.

125 Id. at 593. Interestingly, the majority cites the old Nardone case to justify this conclusion rather than the classic attenuation cases of Wong Sun or Brown.

$126 \quad I d$.

127495 U.S. 14 (1990).

128 Hudson, 547 U.S. at 594.

129 Id.

$130 \quad$ Id.
} 
uncovered after a five-hour search. ${ }^{131}$ It is hard to say why not-Justice Kennedy certainly does not. The only clue is found a few paragraphs later where Justice Kennedy states, "the relevant evidence was discovered not because of a failure to knock and announce, but because of a subsequent search pursuant to a lawful warrant." 132 This claim is surely a but-for causal claim closely akin to the inevitable discovery rule or the independent source doctrine. Nothing in this conclusion suggests that attenuation - as defined by Wong Sun and systematized by Brown - really describes Justice Kennedy's view. The discovery of the evidence in this case was not coupled with an extensive lapse in time between illegal activity and discovery, there was no intervening event which might account for the discovery of the evidence, and the flagrant nature of the police conduct was not even at issue. This lack of doctrinal precision when it comes to causal analysis, and attenuation in particular, has consistently plagued the Court's doctrine.

And so, on the eve of the most recent and, perhaps, the most significant attenuation case-Utah $v$. Strieff - we find the Court's attenuation doctrine to be a bit of a puzzle. After progressing from a single sentence in Nardone to a more formal doctrine in Brown, the ensuing years have seen a Court torn between conflicting and sometimes logically inconsistent approaches. As we have seen, the Court in Kaupp applied the Brown test to the facts and fairly easily dispatched the case. Only three years later, the Court asserts that attenuation applies, but then fails to even mention Brown. Mixed in, throughout the years, are Supreme Court opinions that struggle to articulate a consistent causation-based narrative as to why the evidence discovered was or was not a product of the original Fourth Amendment violation. Sometimes the Court toed the causal line and concluded that the evidence discovered was not a product of the original police conduct because the causal link between the illegal police conduct and the acquisition of the incriminating evidence is too attenuated based on lapse of time, intervening factors, etc. Other times, the Court declined to find such a causal link for purely policy-based reasons. Using policy to define remedy is fine, but it should not be the basis for establishing and applying a fact-based causality analysis. Perhaps now is a good time to discuss causality and the logic behind the attenuation rule.

\section{ATTENUATION AS CAUSATION}

Any discussion of attenuation and its causal origins starts with the simple necessity of a Fourth Amendment violation. When police engage in conduct contrary to the Fourth Amendment, be it an illegal entry, search of a vehicle, or detention of an individual, there are two broad potential consequences. First, the illegal police action could lead to no incriminating evidence, and the suspect is free to carry on his life with no criminal consequences. Second, the illegal police

131 Id. at 603-04 (Kennedy, J., concurring).

$132 I d$. at 604. 
action could lead to the discovery of incriminating evidence of some sort with a subsequent criminal prosecution based solely or in part upon the incriminating evidence discovered. In the second case, the concept of causation helps us to establish a clear linkage between the police action and the evidence discovered. ${ }^{133}$ After this linkage has been established, the obvious question becomes - what do we do about this? For the majority of our existence as an independent republican democracy, the remedy was some sort of civil lawsuit designed to hold the individual police officers accountable for their actions. ${ }^{134}$ This civil remedy is still viewed to be the solution to the first type of Fourth Amendment violation - that which leads to no incriminating evidence. ${ }^{135}$ By the 20th century, however, this civil remedy for the second type of Fourth Amendment violation - that which led to the discovery of incriminating evidence - was replaced with a remedy of greater consequence.

In Weeks v. United States ${ }^{136}$ and Mapp v. Ohio, ${ }^{137}$ the Supreme Court articulated a remedy for such situations that we refer to as the exclusionary rule. The rule is perhaps most concisely articulated by the Court in Mapp which held that "all evidence obtained by searches and seizures in violation of the Constitution is, by that same authority, inadmissible." 138 Contained within this simple proposition is a causal reality. In order for the evidence obtained to be found inadmissible, it must have been "obtained by searches and seizures in violation of the Constitution." In this context, obtained means that the illegal police conduct caused the discovery of the evidence. A rudimentary definition of cause suggests that it is "that which produces an effect." 139 As easy as "cause and effect" may be for us to understand, from a philosophical and a legal perspective the concept is more complex.

Philosophical notions of causation attempt to produce broad generalizations about how the world works by relying upon scientific observation in the hopes of establishing how broad classes of events are

133 In general, as noted by Kenneth S. Abraham, "causation is a conclusion we reach when we expect a certain consequence to follow a certain antecedent and we have what we consider a tenable explanation for this relationship between an antecedent and a subsequent event." Kenneth S. Abraham, Self-Proving Causation, 99 VA. L. REV. 1811, 1815 (2013). He continues, "The more reliable the explanation has been in the past that a particular subsequent event will follow a particular antecedent, and the more coherent the explanation for this relationship, the more convincing is the conclusion that the antecedent cause the consequence." Id.

134 See Akhil Reed Amar, Fourth Amendment First Principles, 107 HARV. L. REV. 757, 786 (1994).

135 See William Geller, Enforcing the Fourth Amendment: The Exclusionary Rule and Its Alternatives, 1975 WASH. U. L.Q. 621 (1975).

136232 U.S. 383 (1914).

$137 \quad 367$ U.S. 643 (1961).

$138 \quad I d$. at 655.

139 Cause, The COMPACt OXFord English Dictionary (2d ed. 1993). 
connected. ${ }^{140}$ Legal notions of causation, however, are more focused. ${ }^{141}$ As noted by Hart and Honoré, "the lawyer ... . [is] primarily concerned to make causal statements about particulars, to establish that on some particular occasion some particular occurrence was the effect or consequence of some other particular occurrence." 142 This concern by lawyers finds expression in the law of torts, criminal law, contracts, and many other areas. ${ }^{143}$ It is in the law of torts that we find the most extensive discussions of causation as it relates to the law of negligence.

In the law of negligence, even when the defendant has breached a clear duty of care to the plaintiff, she will only be held liable if this negligent action (or omission) caused the injuries suffered. ${ }^{144}$ Thus, establishing causation is of primary concern for courts examining these situations. It is all too easy to fall into the logical trap of the post hoc ergo propter hoc manner of examining causation. ${ }^{145}$ This logical fallacy would suggest that because the injury came after the defendant's actions, the defendant's actions must have caused the injury in question. Clearly, this is not the case-but deciding when causation does exist has been no easy proposition.

\section{A. But-For Causation}

The first form of causation typically referenced is that referred to as "causation in fact" or "but-for causation." 146 The "classic test for determining cause in 'fact' directs the 'factfinder' to compare what did occur with what would have occurred if hypothetical, contrary-to-fact conditions had existed." ${ }^{147}$ In other words, the sequence of events that actually occurred-including, for example, the injury suffered by the plaintiff-would not have occurred "but-for" the action of the defendant that set the sequence of events into motion.

\section{H.L.A. Hart \& A.M. Honoré, CAUSATION IN THE LAW 9 (1959).}

141 It can be argued, however, that this focus can distort the meaning. As noted by Michael S. Moore, '[i]t is of course possible that although the law uses the word 'cause,' it does not refer to causal relation." Michael S. Moore, CAUSATION AND ResPonsibility 3 (2009). "It is possible, in other words, that what these doctrines call causation has nothing to do with causation as a real relation in the world; rather, the possibility is that here as elsewhere the law uses a word in a technical, distinctly legal sense, even though the word already has an established meaning in nonlegal English." Id. In this Article, we will argue for the definition of causation to be that of a realworld concept and not just a legal one.

142 HART \& HONORÉ, supra note 140, at 8-9.

143 Id. at 79.

144 W. Page Keeton et Al., Prosser \& Keeton on the Law of Torts $§ 30$ (5th ed. 1984).

145 See Richard H. Underwood, Logic and the Common Law Trial, 18 AM. J. Trial Advoc. 151, 1175-78 (1994).

146 KeETON ET AL. supra note 144, § 30.

$147 \quad$ Id. at $\S 41$. 
But-for causation is recognized as significant in the Supreme Court's discussion of when to view subsequently discovered incriminating evidence as the consequence of prior police Fourth Amendment violations. The Court repeatedly refers to but-for causation as a basis for deciding if the illegal actions of the police caused the eventual discovery of incriminating evidence but also typically concludes that but-for causation is not enough to establish an actionable causal link between the two events. ${ }^{148}$ This reluctance to accept but-for causation as the defining test for establishing a true causal link is perhaps best articulated in Ceccolini where the Court observed, "[e]ven in situations where the exclusionary rule is plainly applicable, we have declined to adopt a 'per se' or 'but for' rule that would make inadmissible any evidence, whether tangible or live-witness testimony, which somehow came to light through a chain of causation that began with an illegal arrest." 149

Given this position by the Court, it might be fair to ask if but-for causation has any role to play in linking illegal acts with subsequently discovered evidence? The Court in Hudson spelled out the role that "but-for" causation plays, noting, "exclusion may not be premised on the mere fact that a constitutional violation was a 'but-for' cause of obtaining evidence. Our cases show that but-for causality is only a necessary, not a sufficient, condition for suppression." 150 As such, we can view but-for causation as a rule of limitation. Without but-for causation, the necessary causal link is not established because the illegal activity of the police was not even a rudimentary "cause" of the discovery of the incriminating evidence-and thus the evidence was not "obtained" by searches and seizures that violated the Constitution.

Aside from the obvious situation in which the illegal conduct by the police has no relationship at all with the subsequently discovered incriminating evidence, but-for causation still plays a role in two complex situations which have led to the promulgation of two specific rules or doctrines to govern its absence. The first, the independent source rule, was first articulated as an exception to the Fourth Amendment by Justice Holmes in Silverthorne Lumber Co. v. United States. ${ }^{151}$ There, Justice Holmes noted that, when there has been a constitutional violation by the police, it does not mean that "facts thus obtained become sacred and inaccessible. If knowledge of them is gained from an independent source they may be proved like any others ...."152 Thus, as the Court observed in Nix v. Williams, "[t]he independent source doctrine allows

148 See Hudson v. Michigan, 547 U.S. 586, 592 (2006); New York v. Harris, 495 U.S. 14, 17 (1990); Segura v. United States, 468 U.S. 796, 815 (1984); Rawlings v. Kentucky, 448 U.S. 98, 106 (1980); United States v. Ceccolini, 435 U.S. 268, 276 (1978); Brown v. Illinois, 422 U.S. 590, 603 (1975); Wong Sun v. United States, 371 U.S. 471, 487-88 (1963).

$\begin{array}{ll}149 & \text { Ceccolini, } 435 \text { U.S. at } 276 . \\ 150 & \text { Hudson, } 547 \text { U.S. at } 592 . \\ 151 & \text { 251 U.S. } 385 \text { (1920). } \\ 152 & \text { Id. at } 392 .\end{array}$


admission of evidence that has been discovered by means wholly independent of any constitutional violation." ${ }^{153}$ This conclusion makes perfect causal sense. ${ }^{154}$ If the illegal conduct of the police was not the "but-for" cause of the discovery of the incriminating evidence, then no Fourth Amendment violation has occurred. In the case of the independent source doctrine, the discovery of the evidence was not caused by the illegal police conduct if other, perfectly legal, police activity uncovered the evidence in question. ${ }^{155}$

Similarly, the Court has also promulgated the inevitable discovery rule as a second "but-for" causation test. When the discovery of incriminating evidence would have inevitably occurred without police misconduct, the fact that it was originally obtained by illegal activity is not a Fourth Amendment violation that requires its exclusion. ${ }^{156}$ From the "but-for" causal perspective, if it can be clearly proved that the evidence would have been uncovered anyway, it can be argued that the original police misconduct was not the "but-for" cause of the discovery of the evidence. Thus, there is no causal link between the Fourth Amendment violation, and the evidence and exclusion would not be appropriate.

Aside from the independent source rule and the inevitable discovery doctrine, however, but-for causation fails to adequately assist our causal analysis of those more complex situations involving the indirect discovery of evidence. The fundamental factual question posed in all Fourth Amendment cases is whether the police actions - which violated the Fourth Amendment - caused the discovery of the incriminating evidence. For many scenarios, the answer is obvious. The Supreme Court has had no difficulty in concluding that a Fourth Amendment violation has occurred when evidence is directly discovered as a result of police illegality. ${ }^{157}$ Thus, it is not too difficult to conclude that evidence discovered on the person of a suspect immediately after an illegal arrest was directly a result of the illegal actions taken by the police. Nothing in this fact pattern demands any conclusion as to what the appropriate remedy for such a violation should be. Reaching a conclusion on causation is more difficult when the evidence is indirectly related to the conduct of the police. For example, the police arrest a suspect without probable cause, and at some later time, the defendant, apparently of his own volition, confesses to the crime. Did the illegal arrest cause the confession? Our problems with indirectly discovered evidence arise when - utilizing our common sense - we have difficulty believing that the police misconduct in question really was the cause of the subsequent discovery

\footnotetext{
153467 U.S. 431, 443 (1984).

155 See MACLIN, supra note 15, at 282.

156 Williams, 467 U.S. at 443-44.

157 Segura, 468 U.S. at 805.
}

154 Despite the common-sense nature of the independent source doctrine, the Supreme Court has struggled to separate the concept from the attenuation doctrine. Thus, in the Segura case, the court notes the 60-year history of the attenuation doctrine only to then suggest that the independent source doctrine is an example of attenuation. Segura v. United States, 468 U.S. 796, 805 (1984). 
of evidence. This disbelief may be due to the fact that other explanations for the suspect's conduct, unrelated to the prior police actions, are the true explanation.

While the Court in Wong Sun held that the exclusionary rule applies to both directly and indirectly discovered evidence, ${ }^{158}$ its subsequent ruling evidences profound unease with concluding that a causal relationship exists in all instances of indirectly discovered evidence where some form of "but-for" causation exists. Hence, the attenuation rule exists. Attenuation is the causal mechanism by which the Court has answered the common-sense question posed above - did the police conduct really cause the subsequent discovery of the incriminating evidence. If the causal relationship between the evidence discovered and the police misconduct is too attenuated, then there really is not a causal relationship at all. Attenuation has evolved very slowly as a concept (as we have seen in the discussion above) and has suffered at the hands of those who wish to equate it with proximate cause - a concept similar to attenuation utilized in the context of the civil law of torts.

\section{B. Proximate Cause vs. Attenuation}

Proximate cause is a concept that has flummoxed law students and lawyers for nearly a century. Also known as "legal cause" in torts, it is used as a mechanism for limiting the reach of the law. From a pragmatic and equitable perspective, courts have had difficulty in imposing liability for negligence to conduct that indirectly produces injuries in unusual and unexpected ways. Relying on "but-for" causation alone would not address these concerns. Hence, proximate cause - a policy-based approach to limiting liability. ${ }^{159}$ As the preeminent hornbook in tort law has observed:

Proximate cause is merely the limitation which the courts have placed upon the actor's responsibility for the consequences of the actor's conduct... [a]s a practical matter, legal responsibility must be limited to those causes which are so closely connected with the result and of such significance that the law is justified in imposing liability. ${ }^{160}$

Using proximate cause as a rule of limitation is pragmatic, but it moves the discussion from the realm of causation to that of policy. As we will see, this

\footnotetext{
158 Wong Sun v. United States, 371 U.S. 471, 484 (1963).

159 The deployment of causal language here falsely suggests some scientific rationale for these normative decisions and obscured their real basis: namely, the determination that the relevant consequences of the wrongdoing full outside the scope of liability that was judged appropriate for the particular legal rule in the light of its purpose.
}

Jane Stapleton, Causation in the Law, in The OXford Handbook of CAusATion 744, 754 (Helen Beebee, Christopher Hitchcock, \& Peter Menzies eds., 2012).

160 KeETON ET AL., supra note 144, § 41. 
policy-based approach has gained ascendency within the Supreme Court's discussion of attenuation, but it is not at all clear that attenuation in the context of Fourth Amendment violations was intended to evolve from a tool for causal analysis to an explanation for policy choices, nor is it clear that such a deviation is wise.

Perhaps, it could be argued, proximate cause based on policy is the reality and attenuation as a causal concept is a pipedream. This would be true if there were no alternative to equating attenuation with the proximate cause notions of modern torts. However, Hart and Honore contend that it is still logically consistent to adhere to the requirement of causation as the sole measure of the imposition of liability - even in situations of unusual and unexpected tort injuries. As they note, causal questions are questions of fact, and "the criteria for deciding them [is] to be drawn from common sense." 161 This then begs the question of what to do in complex situations, not only those involving complicated allegations of negligence, but also with situations in which evidence is indirectly obtained after police misconduct. How can "common sense" help us limit the reach of unconstitutional taint? Hart and Honoré confront this situation as well by observing that even in these complex situations the legal system should avoid reliance on expedience or notions of "justice" and simply ask "how like or unlike the standard clear case the present debatable case is." ${ }^{162}$ In other words, perhaps reliance on facts is not as difficult as we might think. Factfinders can rely upon facts and "what was assumed, rightly or wrongly, to be part of the ordinary man's stock of general notions." 163 This notion of "common sense" driving causal conclusions finds support in the very first attenuation case, Nardone v. United States. There, Justice Frankfurter observed that when assessing the limits of causal connections, we should be able to "rely on the learning, good sense, fairness and courage of federal trial judges." 164 This faith in judicial fact finders is reiterated in Brown. ${ }^{165}$

\footnotetext{
161 HART \& HONORÉ, supra note 140 , at 86.

$162 \quad$ Id. at 87.

163 Id. at 86; see also 1 David Hume, A Treatise of Human Nature 89 (1959). The extent to which we believe that "common sense" is a product of experience. Hume asserts, "All causal inferences depend, in one way or another, on experience of causal conjunctions. Following experience in which objects or events of one kind are generally or always followed by objects or events of another kind, the mind develops, through 'custom or habit,' a propensity to form an 'idea' of an object or event of one of these kinds upon having a 'perception' (which is itself either an 'impression' or an idea) of an object or event of another." Id.; see also Don Garrett, Hume, in THE OXFORD HANDBOOK OF CAUSATION, supra note 159, at 73, 75.
}

Nardone II, 308 U.S. 338, 342 (1939).

165 Brown v. Illinois, 422 U.S. 590, 604 n.10 (1975). 


\section{Brown and Defining Attenuation}

Even assuming that common sense notions of relationships and factual causation can adequately address the difficulties associated with drawing a causal linkage in complex situations of evidence resulting indirectly from illegal police conduct, it would still be useful to provide some factual guides to assist the factfinder in reaching his or her conclusions. The slow evolution of the concept of attenuation in the context of Fourth Amendment violations attempts to assist in this process. The seminal case of Brown v. Illinois provides a partially effective way to examine the facts of a given case so as to establish or refute a causal link between the illegal police conduct and the subsequently discovered evidence. ${ }^{166}$ Two of the three Brown factors comport with our "common sense" notions of causality. ${ }^{167}$

\section{Temporal Proximity}

The first factor, the lapse of time between the offending conduct and the discovery of the incriminating evidence, comports most obviously with the lay definition of attenuation. ${ }^{168}$ As defined, attenuation is the "process of weakening, as if by dilution" or "diminution of characteristic force." " suggest that a causal link can "weaken" or diminish in force over time. ${ }^{170}$ As in Wong Sun, the defendant's reasons for returning to the police station and making an incriminating statement several days after the illegal police conduct would suggest that the import of the police contact had likely diminished or weakened such that it was likely that something else motivated the defendant's conduct. ${ }^{171}$ On the other hand, if a defendant is illegally arrested without probable cause and interrogated soon thereafter, as in Kaupp v. Texas, the confession that was

\section{Id. passim.}

167 For purposes of our further discussion, we will not consider Miranda warnings as part of the "test" set forth in Brown. It is true that the Brown Court concluded that the "Miranda warnings are an important factor . . . in determining whether the confession is obtained by exploitation of an illegal arrest." Id. at 603. However, the significance of Miranda warnings in subsequent cases is de minimis, and it fails to fit well in a causal framework in which the discovery of the incriminating evidence is unrelated to a confession.

168 Temporal proximity is also consistent with David Hume's notion of causation and contiguity. For Hume, contiguity implied not only spatial proximity but also closeness in time. This contiguity was vital, as Hume noted, "[w]e may therefore consider the relation of contiguity as essential to that of causation." HuME, supra note 163, at 78-79.

169 Attenuation, THE COMPACt OXFORd ENGLish DictionARY, supra note 139.

170 It is worth mentioning that lapse of time — or absence of temporal proximity - is a factor typically examined when addressing proximate cause in torts cases. Judge Andrews, in his famous dissent in Palsgraf v. Long Island Railroad Co., points to this factor as one that courts must consider when deciding to extend liability to atypical situations. 162 N.E. 99, 104 (N.Y. 1928).

171 Wong Sun v. United States, 371 U.S. 471, 491 (1963). 
obtained within an hour or so was one where the impact of the police misconduct had certainly not weakened or diminished. ${ }^{172}$ Thus, no attenuation occurred and the causal linkage survived. The temporal proximity test set forth in Brown is consistent with our common-sense appraisal of these types of situations. The more time that elapses, the weaker the influence of the police misconduct on the defendant's behavior, and the less likely it is that this conduct caused the subsequent confession. ${ }^{173}$

\section{Intervening Event}

The second test offered in Brown requires reviewing courts to determine if some "intervening circumstances" could more accurately explain the defendant's confession rather than the lingering influence of the illegal police conduct. ${ }^{174}$ Obviously, a number of intervening circumstances can transpire between illegal police conduct and a subsequent confession. A defendant might ask for a glass of water, might be given the opportunity to make a phone call, have a bite to eat, etc. What we are looking for are intervening factors that could account for the actions of the defendant. Particularly, if we believe that confessing to a crime is not something that all defendants will do automatically, we are looking for circumstances that might explain actions taken by a defendant that might not be in their best interests. ${ }^{175}$ Thus, as the Court stated in Giordano, "the derivative taint of illegal activity does not extend to the ends of the earth but only until it is dissipated by an intervening event." ${ }^{176}$ Characterizing the types of intervening factors that would satisfy the Brown test is difficult. Both Brown and Barry v. New Jersey cite Johnson v. Louisiana as an example of a situation in

\section{Kaupp v. Texas, 538 U.S. 626, 633 (2003).}

173 As mentioned earlier, Justice Stevens, in Dunaway v. New York, argued that the temporal factor was too subjective. 442 U.S. 200, 220 (1979). It could be argued that when there is a lengthy delay between illegal police conduct and a subsequent police interrogation, the impact of delay coupled with the lingering memory of the police misconduct may combine to make the causal relationship between the police misconduct and the confession even greater than if the confession had taken place immediately. Similarly, an immediate confession could be due to a prearrest event, such as a meeting with a minister, and not causally related to the police misconduct at all. Id. While this may be true as speculation, if we view common sense causality as being established by probabilities, Justice Stevens' examples may be outliers that do not inform the general discussion. 174 Brown v. Illinois, 422 U.S. 590, 603 (1975).

175 While this discussion of intervening circumstances is squarely within the broader concept of attenuation according to Brown, the Court in United States v. Crews seems to suggest that an inquiry about an intervening circumstance is somehow separate from the notion of attenuation. As the Court states, "the question before the court is whether the chain of causation proceeding from the unlawful conduct has become so attenuated or has been interrupted by some intervening circumstance so as to remove the "taint' imposed upon that evidence by the original illegality." United States v. Crews, 445 U.S. 463, 471 (1980) (emphasis added). This only illustrates the struggle the Court has had with applying a purely causal concept to fact patterns of this type.

176 United States v. Giordano, 416 U.S. 505, 554 (1974). 
which an intervening factor severed the causal link between the illegal police conduct and the subsequent confession. ${ }^{177}$ Regrettably, Johnson is a poor vehicle for clarifying what types of intervening factors can sever causality and thus support a conclusion that the link between police conduct and incriminating evidence is attenuated. ${ }^{178}$

In Taylor v. Alabama, ${ }^{179}$ the Court provided some guidance by at least indicating the kinds of intervening events that would not dissipate the taint. In Taylor, the defendant was arrested illegally and subsequently confessed. ${ }^{180}$ The state pointed to a brief meeting between the defendant and his girlfriend and a male companion. ${ }^{181}$ Immediately after the meeting, the defendant recanted his prior denials and confessed to the crime. ${ }^{182}$ The state argued, not unreasonably, that this meeting was pivotal in severing the causal link between the illegal arrest and the subsequent confession. The Court, however, found the state's claims "dubious." 183 The Court noted that the evidence suggested that the defendant's girlfriend became upset when she heard the officers advise the defendant to cooperate - which, to the Court, was evidence that the visit would more likely have led the defendant to refuse to cooperate, not confess. ${ }^{184}$ One would have thought that a meeting with a loved one followed by a complete change of heart with respect to cooperation would lead one to conclude that this event was significant - even pivotal — in accounting for the defendant's behavior. Taylor, however, leaves us confused.

We could turn to tort law and criminal law to explore how the concept of an intervening circumstance affects the causal link between an original action

177 Barry v. New Jersey, 454 U.S. 1017, 1020 (1981) (White, J., dissenting); Brown, 422 U.S. at 603-04.

178 Johnson is a case primarily dealing with Louisiana's jury trial rules which permitted a nonunanimous verdict. Johnson also alleged that he was arrested illegally and that a subsequent lineup identification should have been suppressed. The majority implied that the fact that Johnson appeared before a magistrate after his illegal arrest and was advised of his rights somehow dissipated the taint of the illegal arrest. The Court never elaborated on this point, and it is hard, in retrospect, to understand how a common sense understanding of causality would find that this appearance severed the causal link between the illegal arrest and the subsequent lineup. These cases in which the incriminating evidence is not supplied by the defendant directly are particularly difficult to square with the attenuation approach established in Wong Sun and Brown. Johnson v. Louisiana, 406 U.S. 356, 365 (1972).

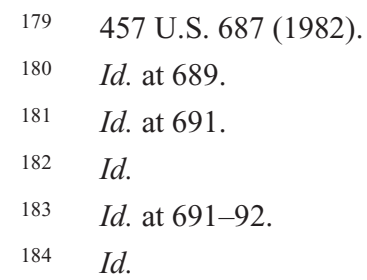


and an ultimate result. ${ }^{185}$ One must be wary, however, of the inclination of tort law (and to some extent, criminal law) to view proximate cause not as a true casual concept, but rather a sorting mechanism to limit the extent of liability. Such an approach may not offer explanations of intervening circumstances that are consistent with a purely causal approach. ${ }^{186}$ Tort law examines intervening circumstances to determine whether the factor in question is a superseding cause. A superseding cause is one which, in torts terminology, "is the only proximate cause because it is the efficient or immediate cause." 187 This definition appears to define one amorphous concept with another that is perhaps just as amorphous. An efficient cause is undefined and defining a superseding cause as one that is immediate inserts a temporal aspect to the quotient, which fails to assist us much at all. As one commentator on the law of torts has observed, the explanations of superseding causes "express conclusions, but none of them offers either reasons or guidance to lawyers." 188 Perhaps even more troubling is the tendency of tort law to focus almost exclusively on the issue of foreseeability. As we will see later in this discussion, foreseeability is not a causal concept and thus adds nothing to a discussion of what factors sever a causal linkage. ${ }^{189}$

Regrettably, criminal law is of no greater assistance to us. As a first step, criminal law often distinguishes between intervening circumstances that are coincidences from those that are a response to a defendant's prior action. ${ }^{190}$ Criminal law tends to limit liability for a defendant whose actions are interrupted by a coincidence as opposed to one whose actions brought others into play-and they cause harm to the victim. ${ }^{191}$ Yet, this is not definitive. Do all coincidental intervening circumstances sever the causal link between the original actor and the ultimate result? The best that criminal law can tell us is - not necessarilyand only when the intervening circumstance has a significance or impact that is "more than a concurring cause." 192 This also is of little assistance. A concurring

185 Tort law often points to the Palsgraf case and Judge Andrews' dissent as a source of law for the belief that intervening circumstances matter when trying to establish proximate cause. Palsgraf v. Long Island R.R. Co., 162 N.E. 99, 104 (N.Y. 1928).

186 As Dan B. Dobbs asserts in The Law of Torts, the "real reason to relieve the defendant of liability is not merely that a new cause has intervened but rather that the risk represented is not one that the defendant negligently created." DAN B. DoBBS, THE LAW OF TORTS 471 (2000) (emphasis added). The problem in what appears to be an imminently sensible statement is the implication that the reason the defendant is not liable is not because of a lack of causation as much as a need to relieve defendant of liability. Id. Causality defines liability; it is not a sorting rule to limit liability for some other purpose. Id.

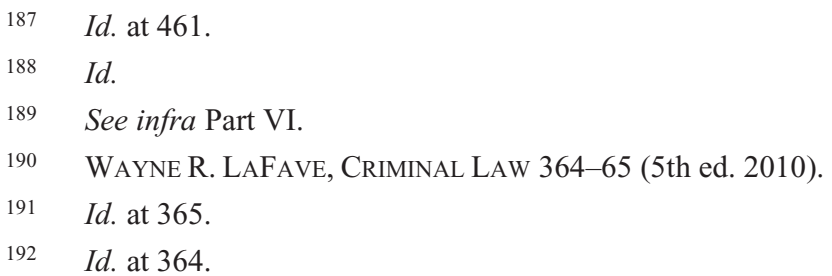


cause is, ostensibly, one that is associated with the original cause or simply a cause that occurs within a window of temporal proximity with the original cause such that they are seen as acting together. In either case, being able to assess when the concurring (intervening) cause is more significant than the original cause - and thus severs the causal connection with the original event-is an exercise in unguided judgment.

A final potential source of enlightenment may be the practices of federal and state courts that attempt to apply the test in Brown to day-to-day facts brought before them. What quickly becomes apparent is that very few cases involve situations in which the attenuation claimed by the state is due to the presence of an intervening circumstance. In those instances where courts do examine alleged intervening circumstances, they nearly always fail to provide any explanation or definition of what constitutes an intervening circumstance of such significance as to attenuate the subsequent incriminating evidence from the illegal police conduct. Rather, the courts tend to simply conclude that an event was an intervening circumstance without really establishing why. ${ }^{193}$

Unfortunately, one of the few attempts to articulate a reason why a particular event would be an intervening circumstance sheds little light. In United States $v$. Smith, ${ }^{194}$ the court indicated that an intervening circumstance can be characterized as one that gives a suspect the opportunity to "pause and reflect."195 Thus, the simple act of reading the consent to search form to the suspect followed by a single question by the suspect was enough to constitute an intervening circumstance because the suspect was given the opportunity to pause and reflect before eventually consenting to the search. ${ }^{196}$ The first problem here is that the court seems to be conflating the temporal proximity test with the intervening circumstance test. The reason to focus on temporal proximity is the commonsense belief that as time passes the immediacy of the illegal police conduct dissipates and it is likely that the defendant's real reason for assisting in providing incriminating evidence is due to a conscious decision predicated on

193 For example, courts have held that providing advice to a suspect of his or her right to refuse to consent to a search acts as an intervening circumstance. United States v. Moreno, 280 F.2d 898 (8th Cir. 2002); State v. Bray, 902 N.W.2d 98 (Neb. 2017). In addition, the opportunity for legal consultation may be an intervening circumstance. Bray, 902 N.W.2d at 98 . Other courts have observed that the termination of unlawful detention, presenting the detainee with new evidence, or evidence that the defendant intended to turn himself in can all be viewed as intervening circumstances. State v. Shaw, 207 A.3d 299 (N.J. 2019). Courts have noted that an independent criminal act may be an intervening circumstance. State v. Tapia, 414 P.3d 332 (N.M. 2018). Finally, of course, several courts have held that the discovery of an outstanding arrest warrant acts as an intervening circumstance. E.g., Sizer v. State, 174 A.3d 326 (Md. 2017). A further discussion of this latter point, in the context of the Supreme Court's decision in Utah v. Strieff, $136 \mathrm{~S}$. Ct. 2056 (2016), will be discussed in much greater detail infra at Part IV.B.

$194 \quad 919$ F.3d 1 (1st Cir. 2019).
$195 \quad$ Id. at 11.
$196 \quad$ Id. at 12.


reflection. Reflection is a temporal factor, yet the Smith court asserts that reflect is the consequence of some event rather than the passage of time. Secondly, there is certainly no guarantee that the administrative actions taken by the police in this case had any causal relevance at all. To assume that hearing a form being read out loud and asking questions about it demonstrates that the suspect had "paused and reflected" is asking a bit much. Thus, without more, the intervening circumstance test makes logical sense but is poorly defined by the courts that have applied it.

Ultimately, it is simply the case that we must rely upon the commonsense notions of the finders of fact to determine if the intervening event is so significant as to negate the causal linkage between the original police misconduct and the subsequently discovered incriminating evidence. That approach, however, runs directly into the Court's most recent decision involving attenuation-Utah v. Strieff. In Strieff, the Court held that the discovery of an outstanding arrest warrant for a defendant who was detained as part of an unconstitutional Terry stop was an intervening factor that explained the subsequent discovery of incriminating evidence on the person of the defendant and severed the causal relationship between the illegal police conduct and the discovery of the evidence. ${ }^{197}$ The defendant argued that the illegal Terry stop undertaken by the police officer was not only a "but-for" cause of the subsequent discovery of the incriminating evidence on his person, following his arrest, but was also the actual or ultimate cause. The Court, however, asserted that this case was similar to Segura v. United States insofar as the Segura court "suggested that the existence of a valid warrant favors finding that the connection between unlawful conduct and the discovery of evidence is 'sufficiently attenuated to dissipate the taint." 198 This, however, is not what the Court held in Segura. Rather, the Court engaged in a "but-for" causation argument to assert that the independent source doctrine justified evidence seized pursuant to a warrant that was not tainted by a prior illegal police entry into the defendant's apartment. ${ }^{199}$ Segura had nothing to do with the question of attenuation and intervening events.

Justice Thomas, writing for the Court, next argues that the nature of the intervening event was such that it simply had to sever the causal linkage between the illegal stop and the subsequently discovered evidence. He contends that, because the officer had a "judicial mandate" to arrest the defendant once the outstanding warrant was discovered, his subsequent act of arresting and searching the defendant was a "ministerial act that was independently compelled by the pre-existing warrant." 200 Finally, Thomas argues that it was "undisputedly

Strieff, 136 S. Ct. at 2062-63.

Id. at 2062 .

199 Segura v. United States, 468 U.S. 796, 815 (1984).

200 Strieff, 136 S. Ct. at 2062-63. 
lawful" for the officer to search the defendant as an incident of the arrest. ${ }^{201}$ All of this may be absolutely true- - but it tells us nothing about causation. Just as it is indisputably true that the officer's actions were ministerial, judicially mandated, and lawful within the immediate context of an arrest, they were also part of a single series of events that all flowed from the illegal stop and would never have occurred without the illegal stop. Thus, the causal link between the illegal stop and the subsequent discovery of incriminating evidence was not severed by the additional actions of the police officer - they merely augmented the causal impact of the original illegal stop. ${ }^{202}$ A common sense approach to causation would have no difficulty in concluding that the illegal stop caused the discovery of the incriminating evidence.

\section{Purpose and Flagrancy of Police Action}

Finally, the Brown court held that it was important to consider the purpose and flagrancy of the police conduct when deciding whether the discovery of incriminating evidence was attenuated from the original illegal police conduct. ${ }^{203}$ Apparently, flagrant conduct is more likely to perpetuate the linkage between police conduct and the subsequent discovery of the incriminating evidence. The Court notes that this third factor is "particularly" significant in assessing attenuation. ${ }^{204}$ Unfortunately, this third test poses the most ambiguity and seems to be the least related to the concept of causality. It is not obvious why the flagrancy of the police misconduct would lengthen or shorten the causal links between the conduct and the ultimately discovered evidence. The Court offers no explanation but does cite three lower federal court decisions in support of this factor. These cases, United States v. Edmons, ${ }^{205}$ United States ex. rel. Gockley v. Myers, ${ }^{206}$ and United States v. Kilgen, ${ }^{207}$ all loosely stood for the proposition that, once the police had engaged in illegal

\footnotetext{
201 Id. at 2063. 180 (7th ed. 2013).

203 Brown v. Illinois, 422 U.S. 590, 604-05 (1975).

$204 \quad I d$. at 604.

205432 F.2d 577 (2d Cir. 1970).

$206 \quad 450$ F.2d 232 (3d Cir. 1971).

$207 \quad 445$ F.2d 287 (5th Cir. 1971).
}

202 It is important to note that there is one situation in which knowledge of other criminal activity involving the defendant can act as an intervening event that severs the causal relationship between the illegal police conduct and the subsequent discovery of evidence. That is when the defendant voluntarily engages in criminal acts as a response to the police activity, and this leads the police to discover incriminating evidence. This "new crime exception" is viewed as either an example of attenuation of the taint of the original illegal police conduct or as a stand-alone, policybased exception to the exclusionary rule. In any event, it seems clear that this exception only applies if "the defendant engaged in further criminal acts." It does not apply to a situation in which prior illegal conduct is discovered. See Kenneth S. Broun et AL., McCormick on Evidence $\S$ 
conduct, the consequence of that conduct depended upon whether they had intended to do so in order to gain some sort of investigative advantage. Thus, in these cases, the operative fact would not simply be police misconduct - it would be police misconduct done for an illicit purpose. ${ }^{208}$ This focus on malign purpose is further emphasized in Brown when the Court observed that the "manner in which Brown's arrest was effected gives the appearance of having been calculated to cause surprise, fright, and confusion."209

Certainly, it can (and perhaps should) be argued that when the police intentionally take advantage of their illegal conduct to gather further incriminating evidence, they should not get the benefits of their illicit tactics. Yet, attenuation is a causal concept and the flagrancy of the police conduct has little to do with causality - at least as it seems to be defined by the Court in Brown and subsequent cases. The concern that Brown appears to have with the flagrancy of the police misconduct has to do with intentions, not causation. ${ }^{210}$ One can envision a situation in which the police are clearly acting illegally by detaining a suspect and they may clearly have intended that such detention would lead to further incriminating evidence, but obtaining a confession is not causally inevitable due to the police intent. Even when the conduct was calculated to cause surprise, fright, and confusion, it could just as easily be the case that the suspect's eventual confession was the consequence of an intervening circumstance such as a long visit with an attorney or pastor, or it could have been the result of a lengthy lapse of time during which the suspect reflected carefully on the situation and chose to confess. On the other hand, one can similarly

208 This interpretation of what the Brown Court meant by "flagrant conduct" is supported by the Court's decision in Dunaway v. New York just four years later. 442 U.S. 200 (1979). There, in a recitation of the Brown factors as applied to the facts of the underlying case, the Court discussed the flagrancy test by stating, "Petitioner was also admittedly seized without probable cause in the hopes that something might turn up ...."Id. at 218. Clearly, the Court viewed the conduct as potentially flagrant because of the intent of the officers.

209 Brown, 422 U.S. at 605. It is important to note that this aspect of Brown has taken on a life of its own in subsequent cases. It hardly seems likely that the concerns regarding surprise, fright, and confusion were the primary concerns associated with the concept of flagrant police conduct. Yet, in Taylor v. Alabama, both the majority and the dissent commented on whether the original illegal arrest was "violent" or involved surprise, fright, or confusion. 457 U.S. 687, 692, 699 (1982). In fact, the majority in Taylor noted that "[t]he fact that the police did not physically abuse petitioner . . does not cure the illegality of the original arrest." Id. at 693. This focus on surprise, fright, and confusion has found its way into lower court decisions as well. See United States v. Wells, 690 F. App'x 338 (6th Cir. 2017).

210 Of particular concern would be that a focus on intentions necessarily renders the evaluation of purpose and flagrancy a subjective process. This potentiality is noted by the Ninth Circuit Court of Appeals in United States v. Garcia, 974 F.3d 1071 (9th Cir. 2020). There, the court observed, "It is not settled whether it is appropriate to examine an officer's subjective intentions in evaluating the 'purpose and flagrancy' of a Fourth Amendment violation. The word 'purpose' suggests a subjective inquiry. But only rarely are Fourth Amendment questions governed by subjective standards, and the Supreme Court has made it clear in the context of the related 'good faith exception' that the inquiry must remain objective." Id. at 1082 n. 8 . 
imagine a situation in which the officer acted with all of the best intentions to protect the rights of the suspect but erred in his understanding of the law. The confession that follows such police misconduct by a matter of minutes without any intervening event is no less causally related to the original misconduct just because the officer made an "honest mistake."

And yet, this "honest mistake" approach seems to have gained some favor in the Supreme Court. In Strieff, the Court states that the officer involved was "at most negligent" and had made "two good-faith mistakes." 211 Justice Clarence Thomas goes on to articulate a view of the facts and the Brown purpose and flagrancy test that looks astoundingly like an elaborate argument for a general "good faith" exception. He characterizes the officer's conduct as an error in judgment ${ }^{212}$ and a "mistaken" decision. ${ }^{213} \mathrm{He}$ further suggests that the failure to demonstrate a "systemic or recurrent" practice by the officer somehow diminishes the original illegality of his conduct. ${ }^{214}$ To wrap up his argument, Justice Thomas characterized this illegal stop as "an isolated instance of negligence." ${ }^{215}$ All of this may be true - but it is utterly irrelevant to the causal question at hand. If the original stop was illegal — and the Court assumes this to be true ${ }^{216}$ - then the well-intentioned nature of the constitutional violation certainly has no impact on the causal relationship between that violation and the subsequent discovery of incriminating evidence. If the intentions of the officer did matter so much, then what the Court should really be advocating for is another "good-faith" exception and not a faithful application of the attenuation rules.

Aside from the fact that flagrancy of police conduct, as defined in Brown, seems directed against intentional police misconduct, which is a noncausal factor, other ambiguities with respect to flagrancy exist. For example, when do we measure the presence or absence of "flagrant" misconduct? Are we only concerned with it at the time of the original event, or can it be important if flagrant misconduct continues? Assume that the original arrest is a violation of the suspect's Fourth Amendment rights, but the police had simply made a mistake. If they then engage in provocative post-arrest conduct that is "flagrantly" inappropriate (i.e. abusive language, demeaning treatment, etc.), does that support causally linking the original misconduct to a subsequent confession? Does it have any relevance at all to the question of causality? If flagrancy is related only to the original incident of police misconduct, does the

\footnotetext{
211 Utah v. Strieff, 136 S. Ct. 2056, 2063 (2016).

$212 \quad I d$.

$213 \quad I d$.

$214 \quad I d$.

215 Id.

216 Interestingly, the Court concedes this point in a very round-about way. It states, "we assume without deciding (because the State conceded the point) that Officer Frackell lacked reasonable suspicion to initially stop Strieff." Id. at 2062.
} 
fact that the Fourth Amendment violation is glaringly obvious make it flagrant? If not, might a better test be "intentionality" rather than flagrancy? While that may be what is meant by flagrancy, it is very unlikely that the Supreme Court would ever embrace a subjective test focusing on intent.

The one thing that we are quite sure about is the popularity of this third test in post-Brown jurisprudence. Most courts dutifully make reference to the Brown Court's comment regarding the particular importance of flagrancy and nearly all suggest that officer flagrancy is "the most important part of the analysis," without articulating why - from a causal perspective - that should be so. ${ }^{217}$ This is particularly disappointing insofar as this particular Brown test is the least likely to provide insights into the causal relationship between the original police misconduct and the subsequent incriminating evidence. ${ }^{218}$ As we shall see, however, this portion of Brown becomes quite important when pursuing other objectives in an attenuation analysis that ignores causality. ${ }^{219}$

Finally, it is important to recognize that the Brown approach to attenuation and many of the cases that follow it may be factually grounded on a situation in which the subsequent incriminating evidence is a direct consequence of the volitional conduct of the defendant. ${ }^{220}$ Thus, after police misconduct, the suspect either confesses or consents to a search, and then the incriminating evidence is uncovered. It may be argued that the kind of causal analysis engaged in by the Court in Wong Sun and Brown is premised on volitional conduct by the suspect which occurs as a consequence of the circumstances commenced by police misconduct. ${ }^{221}$

A causally based attenuation analysis becomes much more difficult if the subsequently discovered evidence is not the result of conduct on the part of the defendant. We can readily understand how the actions of the police would

217 E.g., United States v. Smith, 919 F.3d 1, 12 (1st Cir. 2019); see also Frimmel Mgmt., LLC v. United States, 897 F.3d 1045, 1056 (9th Cir. 2018); United States v. Terry, 909 F.3d 716, 722 (4th Cir. 2018); United States v. Mendez, 885 F.3d 899, 909 (5th Cir. 2018); United States v. Yorgensen, 845 F.3d 908, 915 (8th Cir. 2017); McDaniel v. Polley, 847 F.3d 887, 896 (7th Cir. 2017); United States v. Lebeau, 867 F.3d 960, 973 (8th Cir. 2017).

218 It is worthwhile to question the ramifications of the alleged import of purpose and flagrancy. Could it be the case that when a police officer acts with good faith and no obvious nefarious purpose that this would override - for purposes of attenuation analysis - the impact of temporal proximity and the lack of an intervening circumstance? Surely if that were so, attenuation would have simply morphed into another "good faith exception" to the exclusionary rule. Yet, it is not obvious why that could not happen given the status afforded to the purpose and flagrancy of the police misconduct.

219 See infra Part IV.

220 See Brown v. Illinois, 422 U.S. 590 (1975).

221 This distinction forms a primary part of the Utah Supreme Court's decision in State v. Strieff, 357 P.3d 532 (Utah 2015). There, the court held that attenuation should be limited to instances involving independent acts of defendants, which can be characterized as "independent acts of free will." Id. at 544. 
influence a defendant's behavior and how lapse of time would diminish that influence. But what happens if the subsequently discovered evidence was discovered without the participation of the defendant in any meaningful way? For example, if the police illegally seized a suspect's vehicle and towed it to an impound lot, would it really matter if the police officer looked into the vehicle and observed illegal contraband 20 minutes later or three days later? Does the lapse of time make any difference in our conclusion that the illegal seizure led to the discovery of the evidence?

Similarly, an intervening event may, from the perspective of causality, sever the causal linkage between illegal police conduct and the subsequent discovery of incriminating evidence that was provided by the defendant's independent act of free will. In such a circumstance, the intervening event assumes the role of cause and this is understandable. However, if there is no participation by the defendant in the subsequent discovery of the incriminating evidence, it is extremely difficult to understand how intervening factors fit into the analysis. If we take the example above where the police illegally seize a vehicle and then look into the vehicle to observe illegal contraband, what type of intervening circumstance could possibly sever the causal link between the illegal police conduct and the subsequent discovery of the incriminating evidence? Any intervening circumstance offered could only be one based on policy concerns. Causality simply would not recognize a situation in which the intervening circumstance clearly severs the causal linkage that clearly exists. Rather, attenuation without volitional conduct by a defendant looks much more like the tort notion of proximate cause. As such, it is far more influenced by policy concerns about when causal links ought to be severed. Because it is simply too difficult to assess the causal consequences of an intervening event when the ultimate discovery of evidence is not tied to the volitional conduct of a suspect, common sense would suggest that some other mechanism is necessary to evaluate how responsible the illegal police activity is for the ultimate discovery of evidence. Causality does not work, and we should not be claiming that it does.

\section{Non-CAusal Uses of Attenuation}

The Supreme Court has utilized attenuation as a reason to not extend the taint of a Fourth Amendment violation to the later discovery of incriminating evidence in a number of situations that are not clearly associated with causality. These references to attenuation are really attempts to hijack an existing causal doctrine for purposes that attenuation was never intended to serve. In order to maintain logical consistency in the causal notion of attenuation, these ancillary uses of the concept should be reconfigured to more appropriately reflect their origins and purposes. This section will discuss three main non-causal uses and applications of attenuation: firstly, the interests being served approach, secondly, foreseeability, and lastly, deterrence. 


\section{A. The Interests Being Served Approach}

In Hudson v. Michigan, the Supreme Court articulated what may be the best framing of a non-causal use of attenuation. ${ }^{222}$ There, the Court stated, "[a]ttenuation also occurs when, even given a direct causal connection, the interest protected by the constitutional guarantee that has been violated would not be served by suppression of the evidence obtained." 223 The Court utilized this claim to argue that a clear violation of the knock and announce rule which had a direct causal connection to the discovery of incriminating evidence was "attenuated" because the purpose of the knock and announce rule was not to protect suspects from unlawful warrantless searches. ${ }^{224}$ This argument sounds very much like the limitations placed on finding negligence liability in the context of negligence per se. ${ }^{225}$ When a statute is being relied upon to establish a breach of the duty, courts have required that the defendant's actions be of the type that the statute was designed to prevent and the injuries suffered be of the type that the statute was intended to prevent. ${ }^{226}$

This limitation on liability is logical and serves a useful purpose, but it certainly is not a mechanism to address causation. In the context of Fourth Amendment cases, it is reasonable to conclude that evidence should not be excluded when the violation that led to the discovery of the evidence was of a right that was not designed to protect suspects from illegal searches. Thus, in the context of knock and announce, the reasons for the rule are not to prevent the police from uncovering evidence in an unconstitutional manner. Thus, from this "policy perspective" the remedy for such a violation should not be one designed for an altogether different constitutional violation. All of this makes sense-even if we disagree with the underlying presumptions which support the conclusion. However, this is not attenuation as a causal concept. Causation has nothing to do with this analysis. ${ }^{227}$ In Hudson, the Court even acknowledged that a direct causal connection existed between the actions of the police and the ultimate discovery of the evidence. This non-causal approach to attenuation was reemphasized by the Court in Utah v. Strieff, where Justice Thomas noted that "[e]vidence is admissible when the connection between unconstitutional police conduct and the evidence is remote or has been interrupted by some intervening circumstance, such that 'the interest protected by the constitutional guarantee that has been

\footnotetext{
222 Hudson v. Michigan, 547 U.S. 586, 593 (2006).

223 Id.

224 Id. The Court has reached similar conclusions in United States v. Cecollini, 435 U.S. 268, 279 (1978) and New York v. Harris, 495 U.S. 14, 20 (1990).

225 KeETON ET AL., supra note 144, § 36.

226 Id.

227 Albert W. Alschuler, The Exclusionary Rule and Causation: Hudson v. Michigan and its Ancestors, 93 Iowa L. ReV. 1741, 1761 n.77 (2008).
} 
violated would not be served by suppression of the evidence obtained." ${ }^{228}$ Logical consistency and accuracy require that this "exclusion" be called something (anything) else — but not attenuation.

\section{B. Attenuation and Foreseeability}

Foreseeability is a prominent feature of tort law and proximate cause. In fact, law students often (incorrectly) distill the entire concept of proximate cause down to the simple question of whether the injury suffered was or was not foreseeable. ${ }^{229}$ The sources of foreseeability as proximate cause can be traced to the infamous Palsgraf case in which Judge William S. Andrews mentions this factor prominently in his attempt to craft a test for the presence of proximate cause. ${ }^{230}$ Foreseeability has, regrettably, bled into our discussion of attenuationwith the consequence of undermining the clear causal purpose of attenuation analysis.

Justice Stephen G. Breyer first injects the concept of foreseeability into an attenuation argument in Hudson v. Michigan. ${ }^{231}$ There, in his dissent, he notes that it should be of some significance that the discovery of evidence in the defendant's home after the failure to knock and announce "was a readily foreseeable consequence of their entry and their unlawful presence within the home."232 Foreseeability was important, in Justice Breyer's mind, in establishing a link between the illegal officer conduct and the subsequent discovery of incriminating evidence.

A better example of foreseeability assuming a role in attenuation causal analysis is Justice Elena Kagan's dissent in Utah v. Strieff. ${ }^{233}$ There, Justice Kagan starts with the Brown tests for attenuation but quickly injects foreseeability as a modifier to the intervening circumstances test. ${ }^{234}$ Attenuation, in her opinion, is to be viewed as similar to tort law which allows an intervening

\footnotetext{
228136 S. Ct. 2056, 2061 (2016).

229 Having taught Torts for five years in the past, the author has reached this conclusion firsthand.

$230 \quad$ Palsgraf v. Long Island R.R. Co., 162 N.E. 99, 104 (N.Y. 1928).

231547 U.S. 586, 615 (2006) (Breyer, J., dissenting).

232 Id. Justice Breyer cites the Second Restatement of Torts $\S 435$ to support his assertion. Within the comments, it is noted that "if the actor should have realized that his conduct might cause harm to another in substantially the manner in which it is brought about, the harm is universally regarded as the legal consequence of the actor's negligence." RESTATEMENT (SECOND) OF TORTS $\S$ $435 \mathrm{cmt}$. b (AM. L. INST. 1965). The two crucial words in this comment are first that the conduct "might" cause the harm and that the harm is regarded as the "legal" consequence of the actor's negligence. Clearly, this statement does not support the notion that a common-sense assessment of causality would support a direct causal link between what the actor did and what happened simply because the outcome could have been (or even was) foreseen.
}

136 S. Ct. 2056 (2016).

$234 \quad I d$. at 2072-73. 
circumstance to sever the causal link "only when it is unforeseeable-not when it can be seen coming from miles away." ${ }^{235}$ Justice Kagan relies on Bridge $v$. Phoenix Bond and Indemnity Company, ${ }^{236}$ yet Bridge is a case involving civil fraud in which proximate cause is an appropriate measuring stick for liability, particularly when proximate cause is used as a tool to limit liability in the civil context. ${ }^{237}$ This is certainly an appealing approach. To take law from another area that has been well developed over time and apply it to a similar situation in another area of the law is what lawyers (and judges) are trained to do.

However, this approach can be dangerous when the underlying rationale for the approach taken in one area of the law does not necessarily justify its use in another. Proximate cause, as discussed earlier, has always been a "shortcut" to aid in establishing liability. As such, it has never been viewed as a purely causal tool. Rather, as we discussed earlier, proximate cause is a device to limit liability when we realize that a pure causal approach may extend liability beyond what policy considerations would approve. Foreseeability nicely assists in this process. Causal links are only severed when the intervening circumstance is unforeseeable - yet foreseeability has nothing to do with causality.

Hart and Honoré have made this argument, pointing to the fact that foreseeability is really a "policy" based test rather than one based on causality. ${ }^{238}$ As such, a foreseeability approach to assessing responsibility can be broader in assigning responsibility than that established by causality and can also be much narrower in assigning responsibility than can causality. ${ }^{239}$ Foreseeability can be a limiting factor when it limits responsibility but can also create an expanded notion of responsibility beyond what we would expect with ordinary causality. One might be justified in questioning the relevance of a factor that has such unpredictable consequences. As W. Page Keeton has observed, "the concept of foreseeability so completely lacks all clarity and precision that it amounts to little more than a convenient formula for disposing of the case ...."240 The reality here is simple. As William H. Hardie, Jr. noted, "foreseeability serves no purpose in the causality inquiry." 241 The ability to foresee a particular outcome tells you nothing about what actually caused the outcome. All it does is allow one to sort out the cases of anticipated or "easy" causality from the harder cases in which the causal link is not one that a casual observer would anticipate. It tells us nothing about the validity of the claimed causal link between the precipitating

\footnotetext{
235 Id. at 2073.

236553 U.S. 639 (2008).

237 KEETON ET AL., supra note 144, § 42.

238 HART \& HONORÉ, supra note 140, at 230-31.

239 Id. at 231-32.

240 KeEtON ET AL., supra note 144, § 43 at 297.

241 William H. Hardie, Jr., Foreseeability: A Murky Crystal Ball for Predicting Liability, 23 Cumb. L. Rev. 349, 387 (1992).
} 
event and the ultimate outcome. ${ }^{242}$ As such, it has no utility in attenuation analysis that is predicated on causality.

\section{Deterrence}

The most significant use of attenuation to serve a non-causal purpose is when attenuation is used to support the conclusion that the exclusionary rule would not deter the police misconduct in question-and thus, exclusion is pointless. The linkage between deterrence as a policy objective of the exclusionary rule and attenuation as a causal test designed to define the limits of the taint resulting from a Fourth Amendment violation are not obvious. In fact, after a careful examination, it can be shown that there is no logical connection between the two. In order, however, to fully explore this questionable approach, it is necessary to briefly examine the evolution of the exclusionary rule and the triumph of those who advocate for deterrence as the sole measure of its use.

The exclusionary rule has its origins in federal cases involving police misconduct that led to the discovery of incriminating evidence. In Weeks $v$. United States, ${ }^{243}$ the police entered the defendant's home and searched it on two separate occasions without a search warrant. ${ }^{244}$ The Court was forced to establish a remedy for such a situation and declined to allow the government to utilize the evidence seized from the searches. Rather, the Court observed,

If letters and private documents can thus be seized and held and used in evidence against a citizen accused of an offense, the protection of the 4th Amendment, declaring his right to be secure against such searches and Seizures, is of no value, and, so far as those thus placed are concerned, might as well be stricken from the Constitution. ${ }^{245}$

\footnotetext{
242 One way to illustrate this point is to consider the following fact patterns. Assume a scientist has discovered two previously unknown, but apparently innocuous, substances. The scientist combines the two substances and an explosion occurs. After the fact, a scientific study establishes that the explosion was an inevitable consequence given the properties of the substances. Was it foreseeable that the combination of the two substances would lead to an explosion? No. Was the combination of the two substances the cause of the explosion? Yes. Foreseeability told us nothing about causation. Another example. Defendant is responsible for carrying a rare Chinese vase from an antiques dealer to the home of the purchaser of the vase. Defendant is intoxicated and has strayed into the road several times on his way to the purchaser's home. The last time that he strayed into the road, Driver who is speeding and driving recklessly does not attempt to avoid Defendant, strikes him with the car, and the vase is destroyed. Was it foreseeable that, by attempting to transport the vase while intoxicated, Defendant created a necessary condition for the injury suffered to the vase? Yes. Was Defendant the cause of the injury to the vase? Based on any common-sense principles of causation the answer would be no. See HART \& HONORÉ, supra note 140, at 231-32.

243232 U.S. 383 (1914).

$244 \quad$ Id. at 386.

$245 I d$. at 393.
} 
The Court precluded the use of these documents seized without a warrant in the defendant's trial. This position was reinforced by the Court's decision in Silverthorne Lumber Co., Inc. et. al. v. United States ${ }^{246}$ where the Court stated that " $[\mathrm{t}]$ he essence of a provision forbidding the acquisition of evidence in a certain way is that not merely evidence so acquired shall not be used before the Court but that it shall not be used at all." ${ }^{.247}$

This fairly straightforward approach to illegally seized evidence became complicated when the Supreme Court addressed the same situation in the context of a state court prosecution. In Wolf v. Colorado, ${ }^{248}$ the Supreme Court recognized that the Fourth Amendment prohibition on illegal searches and seizures applied to the states insofar as it was a violation of the Fourteenth Amendment and contrary to our concepts of ordered liberty. ${ }^{249}$ However, the Court struggled to discover an appropriate remedy for this Constitutional violation. Justice Felix Frankfurter started out asserting that no single approach was necessary-a conclusion certainly contrary to the Court's position in Weeks and Silverthorne. ${ }^{250}$ Rather, Justice Frankfurter asserted that the remedies in Weeks and Silverthorne were neither "derived from the explicit requirements of the Fourth amendment" nor were they "based on legislation expressing Congressional policy in the enforcement of the Constitution." 251

As such, the remedy is not mandated by the Constitution and can take many forms. Frankfurter asserted that the states could best determine the remedy that should be provided - including such questionable remedies as civil actions for damages. ${ }^{252}$ Justice Frankfurter also opened the door for the now dominant deterrence argument. He acknowledged that excluding the evidence may "be an effective way of deterring unreasonable searches" but goes on to assert that the states can find other remedies that are less demanding than exclusion..$^{253}$

$\begin{array}{ll}246 & 251 \text { U.S. } 385 \text { (1920). } \\ 247 & \text { Id. at 392. } \\ 248 & \text { 338 U.S. } 25 \text { (1949). } \\ 249 & \text { Id. at 27-8. } \\ 250 & I d . \text { at } 28 . \\ 251 & I d . \\ 252 & I d . \text { at 30. } \\ 253 & I d . \text { at 31. Justice Wiley }\end{array}$

Frankfurter's opinion noting, in part, that "the Amendment without the sanction is a dead letter" Id. at 47 (Rutledge, J., dissenting). There is much academic discussion on the overwhelming influence of Justice Frankfurter on the development of the Fourth Amendment jurisprudence. See MACLIN, supra note 13, at 37-46. Frequently, that discussion portrays Justice Frankfurter's influence as being hostile to the fundamental notions of exclusion. Id. at 40 . In fact, it is interesting to observe that Justice Frankfurter never even specifically acknowledges that the conduct of the Colorado officers was unconstitutional. Id. No mention of the facts is made at all in Frankfurter's opinion, and he seems far more interested in raising questions about the legitimacy of the 
The Supreme Court moved on from Wolf in 1961 with its decision in Mapp v. Ohio. ${ }^{254}$ Here the Court forthrightly confronted a clear Fourth Amendment violation and sought the appropriate remedy in a state court prosecution. Justice Tom C. Clark, who drafted the majority opinion, quickly distanced himself from Frankfurter's approach by observing that the rule established in Weeks was of constitutional origin. ${ }^{255}$ As the majority opinion clearly states, "all evidence obtained by searches and seizures in violation of the Constitution is, by that same authority, inadmissible in a state court."256 Regrettably, Justice Clark did not stop there. Rather, he went on to offer othernon-constitutional-reasons for the exclusionary rule. He observed that the purpose of the exclusionary rule was to deter ${ }^{257}$ and then, later, that judicial integrity mandated an exclusionary rule. ${ }^{258}$ These different "purposes" undoubtedly raised confusion about the nature of the remedy. Was exclusion mandated by the Constitution, or was it simply a judicially created remedy based on practical considerations of deterrence or judicial integrity? If the latter, the application of the rule would depend upon whether it furthered the stated purpose of the rule. If constitutionally mandated, however, there would be no case-bycase assessment of the application of the rule-it would always apply as long as that constitutional mandate existed.

The potential confusion in Justice Clark's opinion was soon exacerbated-by Justice Clark. In Linkletter v. Walker, ${ }^{259}$ Clark wrote a majority opinion addressing the retroactive application of the ruling in Mapp. In the course of the opinion, Clark made clear that the purpose of the exclusionary rule was deterrence - and apparently only deterrence. ${ }^{260}$ As Tracy Maclin notes, "[a]fter Linkletter, the [exclusionary] rule would forever be viewed by a majority of the Court as a deterrent-based remedy, and not mandated by the Constitution itself." 261 This conclusion, in and of itself, says little about the relationship between the exclusionary rule and attenuation. Whether the Court was correct in this conclusion is beyond the scope of our discussion. What we do know is that this conclusion, of a policy nature, has become the prevalent way of evaluating the applicability of the exclusionary rule ever since. Starting in 1968 with Justice

exclusionary rule and suggesting that the only purpose for the rule is deterrence. He, in effect, separates the Fourth Amendment violation from the discussion and focuses only on the remedy. Id. at $37-46$.

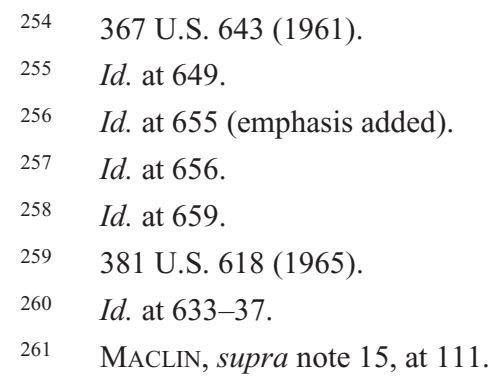


Byron R. White's dissent in Harrison v. United States, ${ }^{262}$ the Supreme Court has become increasingly clear that the only purpose of the exclusionary rule is to deter police misconduct. Justice William J. Brennan, joined by Justice Marshall, pushed back against this claim in United States $v$. Janis noting that "I adhere to my view that the exclusionary rule is a necessary and inherent constitutional ingredient of the protections of the Fourth Amendment." ${ }^{263}$ Surprisingly, 14 years later, Justice Thurgood Marshall grudgingly acknowledged the dominance of deterrence view, noting "[i]n recent years, this Court has repeatedly stated that the principal purpose of the Fourth Amendment's exclusionary rule is to eliminate incentives for police officers to violate that Amendment."264

Sixteen years later, Justice Breyer-often considered to be part of the liberal wing of the Supreme Court-stated in Hudson v. Michigan that, "the driving legal purpose underlying the exclusionary rule [is] the deterrence of unlawful government behavior." 265 In the most recent Fourth Amendment exclusionary rule case heard by the Supreme Court, Utah v. Strieff, the triumph of deterrence theory was complete with the majority opinion and a dissenting opinion by Justice Kagan both formulaically reciting the proposition that the purpose of the exclusionary rule is deterrence as the blackletter law upon which all else follows. ${ }^{266}$

This policy choice is immaterial to an understanding of a causal approach to attenuation. As Justice Breyer noted in his dissent in Hudson, "application of the exclusionary rule is a separate question from whether the Fourth Amendment has been violated." ${ }^{267}$ And this is the point. Attenuation is a mechanism to assess the causal linkage between illegal police conduct and subsequent discovery of incriminating evidence. The conclusion that such a linkage exists means, at root, that the ultimate discovery of incriminating evidence is a Fourth Amendment violation - just as in a situation in which the evidence discovered directly flowed from the violation in question. This is all that attenuation is designed to do. It is not meant to assist in evaluating an appropriate remedy for the situation. It is only intended to establish the presence or absence of a Fourth Amendment violation.

Just as attenuation is not intended to address the question of remedy, it is, thus, not intended to address the issue of deterrence. The separation of these two issues is implicitly recognized by Justice Scalia in his majority opinion in

262392 U.S. 219, 228 (1968) (White, J., dissenting). Justice White's dissent in Harrison is fascinating insofar as his strong deterrent position is based — apparently exclusively — on a 1967 comment contained in the University of Pennsylvania Law Review. Comment, Fruit of the Poisonous Tree-A Plea for Restraint Criteria, 115 U. PA. L. REv. 1136 (1967).

263428 U.S. 433, 460 (1976).

264 New York v. Harris, 495 U.S. 14, 22 (1990).

265 Hudson v. Michigan, 547 U.S. 586, 608 (2006) (Breyer, J., dissenting).

266 Utah v. Strieff, 136 S. Ct. 2056, 2057, 2071 (2016).

267 Hudson, 547 U.S. at 611 (Breyer, J., dissenting). 
Hudson v. Michigan. ${ }^{268}$ Nevertheless, over time, some members of the Court have attempted to tie the concept of attenuation to the remedial considerations associated with deterrence. This linkage makes no sense in terms of what attenuation is intended to do, nor do our measures of attenuation add anything to an assessment of the propriety of deterrence as justification for the remedy of exclusion. ${ }^{269}$

The first attempt to tie these two concepts together can be found in the concurrence in part opinion in Brown drafted by Justice Lewis F. Powell Jr. and joined by Chief Justice William H. Rehnquist. They argued that attenuation should be viewed as the means by which we can "mark the point at which the detrimental consequences of illegal police action become so attenuated that the deterrent effect of the exclusionary rule no longer justifies its cost." ${ }^{270}$ Powell goes on to argue that "the Wong Sun inquiry always should be conducted with the deterrent purpose of the Fourth Amendment exclusionary rule sharply in focus." 271 Thus, from Justice Powell's perspective, the purpose of attenuation analysis is not to establish the causal relationship between the police misconduct and the subsequently discovered evidence, but rather to draw a line beyond which exclusion will not occur-irrespective of causation-due to the deterrent consequences. ${ }^{272}$ As such, attenuation is used to assess the admissibility of the evidence, not its causal relationship to a prior Fourth Amendment violation.

In Dunaway v. New York, the Court in an opinion drafted by Justice Brennan offers a different view of the relationship between deterrence and attenuation. He stated:

Brown's focus on the 'causal connection between the illegality and the confession' reflected the two policies behind the use of the exclusionary rule to effectuate the Fourth Amendment. When there is a close causal connection between the illegal seizure and the confession, not only is exclusion of the evidence more likely to deter similar police misconduct in the future, but

268 There, Justice Antonin G. Scalia notes, "Quite apart from the requirement of unattenuated causation, the exclusionary rule has never been applied except 'where its deterrence benefits outweigh its "substantial social costs."'" Id. at 594 (emphasis added).

269 Fairness requires recognition of the fact that Justice Marshall — an ostensible opponent to the "deterrence only" theory of the exclusionary rule-acknowledges the linkage between deterrence and attenuation by observing that "our attenuation analysis must be driven by an understanding of how extensive exclusion must be to deter violations of the Fourth Amendment." New York v. Harris, 495 U.S. 14, 22 (1990) (Marshall, J., dissenting). Despite this, however, Marshall goes on to explain attenuation as an attempt to discern if "a suspect's statement is properly attributable to a Fourth Amendment violation or to the suspect's independent act of will. ..." Id. at 23. Clearly, this is a causal question, not a policy-based question.

270 Brown v. Illinois, 422 U.S. 590, 609 (1975) (Powell, J., concurring in part).

$271 \quad$ Id. at 612.

272 Id. at $612-13$. 
also use of the evidence is more likely to compromise the integrity of the courts. ${ }^{273}$

The Supreme Court reemphasized this ostensible linkage between causal analysis and deterrence in Barry v. New Jersey. ${ }^{274}$ On one level, it can be argued that Justice White is acknowledging that there is a two-step process: first, establish a causal link, and second, make a policy based decision on whether the exclusionary rule should be applied. ${ }^{275}$ However, the argument that deterrence is more effective when a close causal relationship has been established suggests that there is some logical linkage between causality and deterrence. Such a logical linkage certainly was not established by the Court's decision in Dunaway.

Ultimately, the Supreme Court in Strieff made the strongest argument that one aspect of the Brown attenuation test was primarily focused on deterrence. Focusing on the third part of the Brown test - that which examines the purpose and flagrancy of the police misconduct-Justice Thomas, writing for the majority, claimed that this "third factor of the attenuation doctrine reflects [the purpose of the exclusionary rule to deter] by favoring exclusion only when the police misconduct is most in need of deterrence - that is, when it is purposeful or flagrant." 276

The risk of joining deterrence and attenuation is the consequent tendency to skew the manner in which the presence or absence of attenuation is assessed. This, coupled with the lack of a clear causal purpose for the third Brown test (the purpose and flagrancy of the police conduct), can create a perfect storm of policy dominating causation. This is perhaps best illustrated by Justice Rehnquist's dissent in Dunaway v. New York. ${ }^{277}$ Rehnquist correctly identifies the various Brown tests and defines the question as whether the "inculpatory statements were sufficiently a product of free will to be admissible under the Fourth Amendment." ${ }^{278}$ While the accuracy of this statement is debatable, ${ }^{279}$ Rehnquist goes on to assert a more troubling argument. He suggests that, because deterrence is the only purpose for the exclusionary rule, the third Brown test is the most important. As such, "[w] here police have acted in good faith and not in a flagrant manner, I would require no more than that proper Miranda warnings be given

\footnotetext{
273 Dunaway v. New York, 442 U.S. 200, 217-18 (1979).

274 Barry v. New Jersey, 454 U.S. 1017, 1019 (1981) (White, J., dissenting).

275 See generally id. at 2017.

276 Utah v. Strieff, 136 S. Ct. 2056, 2063 (2016).

277 Dunaway, 422 U.S. at 221 (Rehnquist, J., dissenting).

$278 \quad I d$. at 226.

279 See New York v. Harris, 495 U.S. 14, 23 (1990) (Marshall, J., dissenting). There, Justice Marshall in dissent notes, "Attenuation analysis assumes that the statement is 'voluntary' and asks whether the connection between the illegal police conduct and the statement nevertheless requires suppression to deter Fourth Amendment violations." Id.
} 
and that the statement be voluntary within the meaning of the Fifth Amendment." 280

This expansion of the "good faith" approach effectively eliminates attenuation - as a causal concept-from the calculation. No longer are we concerned with if A's actions caused B. Now we only ask if A was well intentioned. Once again, we can imagine a situation in which the first two tests in Brown suggest that attenuation does not exist, and thus a Fourth Amendment violation has taken place. Yet, the third factor in Brown so obviously favors attenuation that it overrides the finding of taint extending from a prior Fourth Amendment violation, and the evidence is thus admissible. This later conclusion is exclusively based on deterrence and the Court's attitudes regarding "good faith" exceptions - in other words, policy and not causality. Even when causality exists, it can be negated by policy.

Similarly, Justice Thomas in Utah v. Strieff asserts that the attenuation doctrine stands for the proposition that "[e]vidence is admissible when the connection between unconstitutional police conduct is remote or has been interrupted by some intervening circumstance." ${ }^{281}$ The problem here is that attenuation has nothing directly to do with admissibility. Attenuation is relevant in determining if the ultimately discovered evidence is the consequence of a Fourth Amendment violation. Other factors - many of them policy baseddetermine the admissibility of the evidence. It is true that without causation and, thus, a Fourth Amendment violation, there is no issue regarding admissibility. That, however, is not the point of Justice Thomas's comment and is not how the Court seems to view attenuation today. As Thomas concluded his majority opinion in Strieff, "we hold that the evidence discovered on Strieff's person was admissible because the unlawful stop was sufficiently attenuated by the preexisting arrest warrant." 282 Again, concluding that attenuation exists does not, in and of itself, render the evidence admissible. Rather, the Court's policy conclusion that deterrence is not served by excluding the evidence in such a situation is the basis for its admissibility. This distinction is vital. Causality (and logic) do not change over time. Policy based reasons for judicial action do. By infusing attenuation with policy, the Court now subjects the concept to the winds of change that constantly batter the Court. Causality should not be subject to such uncertainty.

\section{RESTORING CAUSATION TO ATTENUATION}

It is time to return attenuation to its origins - as an approach to establishing causality in those complicated situations in which evidence is indirectly discovered after a clear Fourth Amendment violation. By limiting the

\footnotetext{
280 Dunaway, 442 U.S. at 226.

281 Strieff, 136 S. Ct. at 2061.

282 Id. at 2063.
} 
application of the attenuation doctrine to a more narrowly defined type of case, redefining some aspects of the Brown approach and, finally, eliminating one of the Brown tests altogether, it is possible to craft a purely causal evaluation of those complicated situations of indirectly discovered incriminating evidence.

\section{A. Limiting Attenuation to Those Occasions When We Evaluate an Independent Act of Free Will}

One of the simplest ways to avoid some problems posed by the Supreme Court's attenuation jurisprudence is to simply limit its applicability. Courts should only utilize the attenuation doctrine to analyze situations in which the subsequently discovered incriminating evidence is the consequence of a volitional act by the defendant. ${ }^{283}$ In other words, it should only be applicable to those situations in which the defendant either subsequently confesses after a Fourth Amendment violation or consents in some way to a physical search. This would confine attenuation to those occasions in which we evaluate the defendant's independent act of free will. This approach to attenuation was perhaps best articulated by the Utah Supreme Court in State v. Strieff. ${ }^{284}$ There, the Court observed that "[t]he origins of attenuation are in cases involving independent acts of criminal defendants...[a]nd the logic and terms of the attenuation doctrine. . . are focused on separating the initial police illegality from the subsequent, independent acts of a defendant." 285

If we look at the history of attenuation in the United States Supreme Court, we first note that the seminal cases involving the concept-Wong Sun and Brown - are both cases that deal with the subsequent volitional conduct of the defendant that led to incriminating evidence. Hence, at its origins, attenuation was a limited concept of causality. Similarly, those cases that seem to stretch attenuation beyond its natural limits - cases such as Hudson and Strieff - involve the discovery of evidence after a Fourth Amendment violation without any volitional acts by the defendant leading to the discovery. The concept described in Wong Sun and the tests articulated in Brown were designed to assist in assessing causal links between police conduct and subsequent volitional conduct by the defendant, not links between illegal police conduct and then additional police conduct — such as in Hudson and Strieff. This limitation will significantly contribute to a purer notion of attenuation as a causal concept.

283 See George M. Derry III, “Allowing Lawless Police Conduct” in Order to Forbid "Lawless Civilian Conduct": The Court Further Erodes the Exclusionary Rule in Utah v. Strieff, 44 HAstings CONST. L.Q. 393, 422-23 (2017).

284357 P.3d 532 (Utah 2015).

285 Id. at 544. 


\section{B. Limiting the Definition of Intervening Events}

Next, courts should reconceive the concept of intervening events to exclude those events that are undertaken by the police themselves. This revision is best understood in light of the Supreme Court's arguments in Strieff. In Strieff, the majority argued that the discovery of an outstanding arrest warrant for the defendant was an intervening event which severed the causal chain connecting the original Fourth Amendment violation to the subsequent discovery of incriminating evidence once Strieff was arrested. ${ }^{286}$ This fails to recognize two realities. First, the police conduct in uncovering the arrest warrant was part of a continuous cycle of events commencing with the illegal Terry stop with no serious lapse of time. As Justice Thomas admits, the discovery of the evidence took place "only minutes after the illegal stop." 287 There was no intervening event, just one long course of police action.

This leads to the second problem. The intervening event in the Strieff case was a product of the actions of the very same police officer that violated Strieff's constitutional rights in the first place. Make no mistake, the discovery of the arrest warrant was the consequence of police conduct. The officer had to ask Strieff for identification and then submit this information to the station, while knowing all along that the purpose was to search for outstanding warrants. ${ }^{288}$ Only after this conduct does the officer undertake the "ministerial" act of arresting Strieff and searching his person. ${ }^{289}$ The discovery of the evidence was the consequence of police action. In situations such as this, our notion of attenuation should not recognize police conduct as an intervening event. Assume, for example, that Officer Smith illegally arrests suspect A and transports him to the police lockup. Assume that less than an hour later Officer Smith visits A in his cell, brings him some cookies and a glass of milk, expresses his regret at having to arrest a nice guy like him, and offers to pray with the defendant. If the defendant subsequently confesses, even if we can honestly say that the actions of Officer Smith caused the subsequent confession, should we really recognize this as an intervening event that dispelled the taint of the unconstitutional arrest? Common sense fact finders would likely say no. ${ }^{290}$

\section{Strieff, 136 S. Ct. at 2062. \\ 287 Id. at 2062.}

288 Justice Thomas seems to acknowledge the sequence of events precipitated by the officer when he notes that "[a]s part of the stop, Officer Frackrell requested Strieff's identification." Id. at 2060. It is important to note that this is not an argument in favor of Justice Kagan's foreseeability approach. It makes no difference to this argument if Frackrell expected to discover an outstanding warrant or not.

\section{Id. at 2063.}

290 The Supreme Court has recognized this concern to some degree in Barry v. New Jersey where it held that it was not an intervening event of significance when, after an illegal arrest, the police confronted the defendant with incriminating evidence. Thus, the confession obtained after 
The consequence of such a provision would be to simplify the notion of attenuation. Given that the purpose of examining intervening events is to determine if they were responsible for the subsequent acts of the defendant rather than the original Fourth Amendment violation, it is much easier to do this if the event in question is truly significant and new. Trying to unravel the consequences of two separate acts both committed by the same agent - the police-is simply too difficult. Just as some would assume that all actions taken by the police are part and parcel of a single course of action, others might actually attempt to sort out what action was responsible for the defendant's subsequent volitional actions. This would likely produce widely disparate results. The best evidence of this has been court decisions following Strieff. Rather than producing a clear rule that the presence of an unrelated, pre-existing warrant acts as an intervening event that severs the causal link between the prior Fourth Amendment violation and the subsequently discovered evidence, some courts have focused in on the Supreme Court's language that such a situation "strongly favors the State" 291 and have concluded that perhaps the presence of the warrant is just some evidence of attenuation. ${ }^{292}$ Other courts have found ways to distinguish Strieff altogether based on the situation. ${ }^{293}$ By removing intervening police activities from consideration as potential intervening events that sever causation we allow a more straightforward assessment of whether something else caused the defendant's cooperation aside from the conduct of police.

\section{Remove Test Three from Brown}

A somewhat more radical reform would remove any reference to the purpose and flagrancy of the policy conduct when considering if attenuation is present. As this Article has previously argued, the flagrancy of police conduct is not an obvious factor in assessing causality. It is difficult to articulate a reason for why flagrant violations of the Fourth Amendment would cause a defendant to confess later on while a "good faith" mistake would not. The Brown Court seems to suggest two reasons for the linkage. First, Brown does suggest that police violations of the Fourth Amendment that are undertaken for the purpose

this was not attenuated. 454 U.S. 1017, 1020-21 (1981) (White, J., dissenting). Similarly, in Taylor v. Alabama, the Court held that the fact that the police had obtained an arrest warrant for the defendant for an unrelated offense did not sever the causal link between the original illegal arrest and the subsequent confession. 457 U.S. 687, 692-93 (1982). In both of these cases, the intervening event was an action undertaken by the police.

291 Strieff, 136 S. Ct. at 2062.

292 See United States v. Lowery, 935 F.3d 638, 644 (8th Cir. 2020); United States v. Gaines, 918 F.3d 793, 800 (10th Cir. 2019).

293 See United States v. Hunter, No. 18-cr-00542-RS-1, 2019 WL 2353121, at *4 (N.D. Cal. May 31, 2019). Here the Court suggests that because the Fourth Amendment violation occurred in a home rather than on the street - as in Strieff - the presence of the prior arrest warrant does not support a conclusion of attenuation. Id. 
of subsequently obtaining a confession or consent to search are particularly reprehensible. ${ }^{294}$ Accepting that as a given, it does not mean that the police purpose has anything to do with what caused the defendant to confess. In most cases, the defendant would not even be aware of the police's purpose when acting as they did. Thus, from this perspective, police purpose as an attenuation test may simply be a means to deny scheming police officers the opportunity to successfully argue attenuation. This is a policy choice - not one tied to causality.

Brown also argues that the flagrancy of the police conduct is tied to situations in which the officers conduct "gives the appearance of having been calculated to cause surprise, fright, and confusion." 295 The argument seems to be that conduct such as this will impress itself upon the mind of the defendant in such a way as to be almost inevitably the cause of subsequent voluntary actions by a defendant that lead to incriminating evidence. Such an argument does have causal merit. However, this would seem to limit this factor's relevance to the most extreme situations. What are we to do in those situations in which the police misconduct doesn't rise to this level of flagrancy? Is factor three then simply a nullity or, as the Supreme Court has argued, does this lack of flagrancy support a finding of attenuation? Such a conclusion is hard to understand. How can it be that if a police officer violates a defendant's Fourth Amendment rights, but does so politely, that there is less chance of a causal linkage between the Fourth Amendment violation and the subsequent confession? The defendant is still impermissibly seized or even locked up - even if the officer did have a smile on his face.

Eliminating factor three eliminates this bizarre outcome. Causality should be determined by factors that assist in assessing the presence or absence of a causal link. Perhaps best of all, elimination of factor three eliminates the linkage between attenuation and the policy objective of deterrence that has migrated into recent Supreme Court decisions. This impermissible linkage is most obviously found in Strieff where Justice Thomas states that factor three assists the Court by "favoring exclusion only when the police misconduct is most in need of deterrence - that is, when it is purposeful or flagrant." ${ }^{296}$ While an inquiry into the purpose and flagrancy of police conduct may inform us as to the likelihood that exclusion will deter such conduct in the future, it tells us nothing about causality. Justice Thomas doesn't even mention the concept of causality when discussing factor three. Removing this factor does nothing to affect the causal utility of the attenuation concept, but it certainly allows us to sever this causal question from any considerations of the appropriate remedy.

\footnotetext{
294 Brown v. Illinois, 422 U.S. 590, 605 (1975).

$295 \quad I d$.

296 Strieff, 136 S. Ct. at 2063.
} 


\section{A Totality Approach}

Perhaps one of the most frustrating aspects of the Brown case is its failure to assist the future finder of fact in assessing the impact of the factors listed as a whole. In other words, how do we weigh each factor? Are some factors necessary? Sufficient? Are some factors more important than others? Without such direction we see courts struggling to assess situations where some factors are present, and some are not. Is this a simple case of math - whichever side had the largest number of factors wins? Or can the impact of a single factor be so significant as to override anything else? It is possible to overcome these problems with a simple formula - the totality of the circumstances.

Often the totality of the circumstances approach gets a bad rap. It can be seen as the last refuge for a court when no better approach is readily apparent. Yet, there are occasions, particularly when making factual conclusions, when the totality of the circumstances best articulates the searching approach the finder of fact must undertake. How might such an approach work in the context of attenuation? First, we have to remember what we are asking. Keeping in mind the changes suggested above, the question becomes, "Did the police violation of a suspect's Fourth Amendment rights cause him or her to ultimately confess or consent to a physical search of some sort?" We know, from the remaining factors from Brown - temporal proximity and presence of an intervening event- that there are some specific things we should look for when answering the question.

We also know that these factors can support different conclusions. A lapse of a short period of time is viewed as supporting the claim that there is a causal link between the Fourth Amendment violation and the subsequent confession or consent. Thus, a claim of attenuation is not supported. Similarly, the absence of any intervening factors supports that claim that the causal link described above is present and attenuation is not likely. On the flip side, similar conclusions can be drawn. A lengthy lapse of time or a significant intervening event can be seen to sever the causal link and can be viewed as supporting the claim of attenuation. What happens, however, when only one of the factors supporting attenuation is present? In other words, a lengthy lapse of time and no intervening event or a short lapse of time and an intervening event? Without the third factor of "purpose and flagrancy" to break the tie, what do we do?

It is now that the common-sense notions of causality come into play. The finder of fact needs to examine the "totality of the circumstances" and simply decide if it is more or less likely that the Fourth Amendment violation was the ultimate cause of the confession or consent. ${ }^{297}$ United States v. Walker offers us an interesting case study. ${ }^{298}$ The police engaged in an impermissible stop-a

297 See, e.g., Wright v. State, 108 N.E.3d 307, 316 (Ind. 2018) ("In application, the federal attenuation doctrine essentially considers the totality of the circumstances surrounding the illegality and the discovered evidence.").

298 United States v. Walker, 965 F.3d 180 (2d Cir. 2020). 
Fourth Amendment violation. ${ }^{299}$ The evidence discovered included an admission by the defendant that drugs were on his person. ${ }^{300}$ The Court concluded that temporal proximity favored the defendant's claim of a causal link between the impermissible stop and the confession. ${ }^{301}$ However, an intervening factor of significance (the discovery of an outstanding arrest warrant) favored the government's claim of attenuation. ${ }^{302}$ Without the third factor (which was hotly disputed in the Walker case), what should we do? A court possessed with reason, experience, and a modicum of common sense should examine all the circumstances - particularly the two remaining Brown factors - and reach a conclusion on causality. Such a conclusion may not be perfect. It may not even be accurate all of the time. But it will be the kind of causal conclusion that ordinary people reach all of the time. And, perhaps most importantly, it will be free from the confusing side issues, illogical assumptions, and policy-based considerations of the appropriate remedy that the Supreme Court has injected into the causal fact-finding process over the past 45 years.

\section{CONCLUSION}

Attenuation, as a causal concept, has great value for fact finders. By limiting the breadth of a Fourth Amendment violation to those events that are actually caused by the violation itself, we allow the fact finder to rationally restrict the awesome consequences of a Fourth Amendment violation to only those situations in which a severe remedy is merited. Regrettably, attenuation as a Fourth Amendment concept has atrophied over time and has morphed into something that has very little to do with causation. Whether it is used by advocates of the deterrence theory of the exclusionary rule to limit the scope of the remedy, or whether it is so overly defined as to create a morass of contradictory tests that fail to work together well, attenuation is in dire need of reform.

Attenuation needs to return to its roots as a purely causal concept. As such, it will allow the finder of fact, using his or her common sense, to identify those situations in which the illegal activities of the police actually caused the criminal defendant to do something which was incriminating - either confessing or consenting to a search of his effects. While this does not seem to be much, it is enough. By focusing on this one task, finders of fact can accurately limit the consequences of a Fourth Amendment violation to only those situations in which the conduct of the police actually mattered.

$\begin{array}{ll}299 & \text { Id. at } 183 . \\ 300 & \text { Id. at } 185 . \\ 301 & \text { Id. at } 188 . \\ 302 & I d .\end{array}$


A failure to address the attenuation problem will, ultimately, lead to its demise as a meaningful concept. The Supreme Court has expanded the "good faith exception" to cover a number of clear Fourth Amendment violations, and it would take very little to see this approach subsume the entire attenuation doctrine. In other words, if all that really matters is whether the office acted in good faith when they violated a suspect's Fourth Amendment rights, then the third prong of the Brown test is the only prong that matters. For those examples of "good faith" police misconduct, causation is no longer relevant. Such an approach would result in the rendering of policy-based decisions before it has been established that, factually, such a policy-based decision is even necessary. Such an outcome will, inevitably, lead to public discontent with the law. Establishing the fundamental facts must come first-irrespective of the policy choices that such facts force us to make.

By returning to the fact-based, causal roots of the attenuation doctrine, the Court can achieve judicial efficiency and clarity in an area of the law that has been notorious for its lack of clarity over the past few years. Attenuation serves as the sorting mechanism for policy-driven remedy choices. Only when there is a clear causal linkage between illegal police conduct and subsequently discovered incriminating evidence does the Court need to get involved. As our history of attenuation has illustrated, cases involving simple factual disputes on the application of the attenuation doctrine are rarely before the Supreme Court. This is due, in large part, to our lower courts' ability to effectively sort out the wheat from the chaff. Invariably, when the Supreme Court has gotten involved in attenuation issues (e.g., Utah v. Strieff), the consequence has been to muddy the waters and make the factual determination more difficult. If we can strip away all of the gloss that has attached itself to the attenuation doctrine, that which is left will more than adequately serve the purpose of causal fact-finding. 